BIS WORKING PAPERS

No. 83 - January 2000

\title{
SWITCHING FROM SINGLE TO MULTIPLE BANK LENDING RELATIONSHIPS: DETERMINANTS AND IMPLICATIONS
}

by

Luísa A Farinha and João A C Santos

BANK FOR INTERNATIONAL SETTLEMENTS

Monetary and Economic Department

Basel, Switzerland 
BIS Working Papers are written by members of the Monetary and Economic Department of the Bank for International Settlements, and from time to time by other economists, and are published by the Bank. The papers are on subjects of topical interest and are technical in character. The views expressed in them are those of their authors and not necessarily the views of the BIS.

Copies of publications are available from:

Bank for International Settlements

Information, Press \& Library Services

$\mathrm{CH}-4002$ Basel, Switzerland

Fax: +41 61 / 2809100 and +4161/2808100

This publication is available on the BIS website (www.bis.org).

(C) Bank for International Settlements 2000.

All rights reserved. Brief excerpts may be reproduced or translated provided the source is stated. 


\title{
BIS WORKING PAPERS
}

No. 83 - January 2000

\section{SWITCHING FROM SINGLE TO MULTIPLE BANK LENDING RELATIONSHIPS: DETERMINANTS AND IMPLICATIONS}

by

Luísa A Farinha and João A C Santos*

\begin{abstract}
Our results show that the majority of firms borrow for the first time from a single bank, but soon afterwards some of them start borrowing from several banks. Duration analysis shows that the likelihood of a firm substituting a single with multiple relationships increases with the duration of the single relationship and that firms with more growth opportunities and more bank debt are more likely to initiate multiple relationships. Firms with poor performance, too, are more likely to initiate multiple relationships. The analysis of the ex post effects of the initiation of multiple relationships does not detect an increase in the firm's overall indebtedness and investment, but it finds an increase in its trade credit reliance and no improvement in its performance. Overall these results suggest to us that a potential unwillingness by the incumbent bank to increase its exposure to a firm because of its past poor performance appears to explain better firms' decision to initiate multiple relationships than the hypothesis that they do so to protect themselves against the hold-up rents inherent to exclusive relationships because they have many growth opportunities.
\end{abstract}

* The authors are economists at the Bank of Portugal and the Bank for International Settlements respectively. They thank Mark Flannery, Stanley Longhofer, David Smith, Steven Ongena, Pedro Portugal, Mário Santos, Reint Gropp, Kostas Tsatsaronis, Oved Yosha and seminar participants at the Bank for International Settlements, the European Central Bank and the 1999 FMA International meetings for useful comments and suggestions, and Lucena Vieira for valuable data assistance. The views stated herein are those of the authors and are not necessarily the views of the Bank of Portugal or of the Bank for International Settlements. 



\section{Contents}

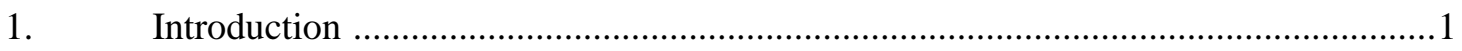

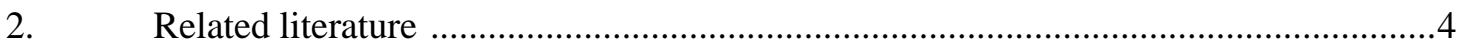

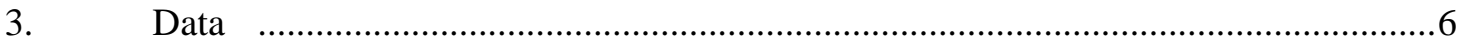

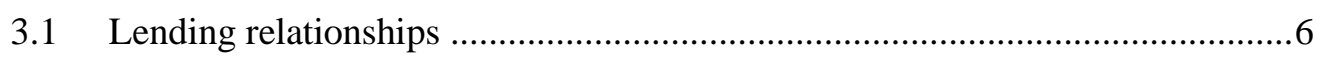

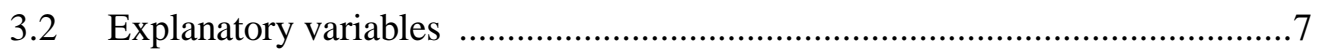

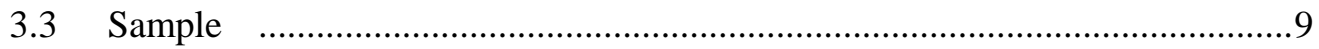

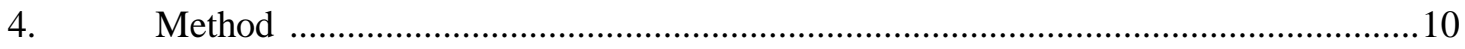

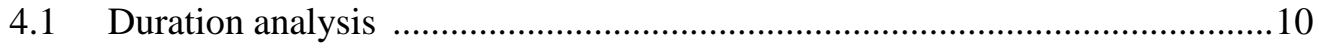

4.1.1 Explanatory variables and the hazard function ...............................10

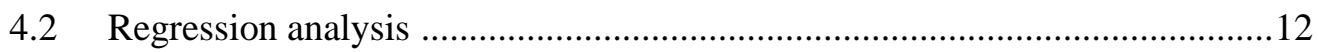

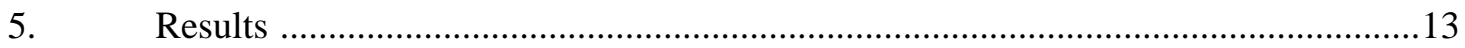

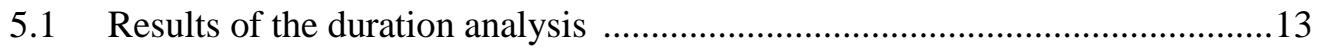

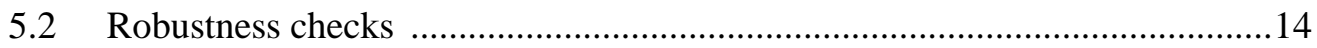

5.2.1 The Weibull assumption on the distribution of duration ..................14

5.2.2 The assumption on the time path of the explanatory variables .......14

5.2.3 The exogeneity assumption of the variable "number of switches" 14

5.2.4 Distinguishing switches from initiations of multiple relationships 15

5.3 A possible interpretation of the results .....................................................16

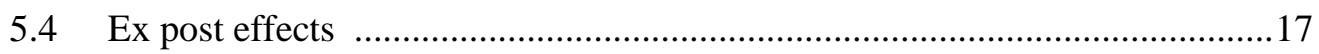

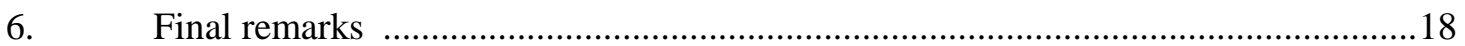

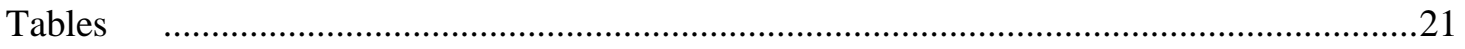

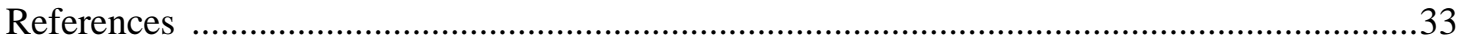





\section{Introduction}

This paper presents empirical evidence showing that the vast majority of firms borrow for the first time from a single bank. Soon afterwards, however, many of them switch banks and others start to borrow from multiple banks. Why do firms switch banks or start to borrow from multiple banks as opposed to continuing to borrow from one bank and improve on the relationship with it? What are the implications of these changes? Our paper attempts to shed light on these questions using a unique data set containing information on individual bank lending relationships since the beginning of firms' life.

Modern banking literature argues that banks are valuable because firms have information that is not readily available to outsiders. Rather than having investors collect information on the firm's prospects prior to granting credit, investors find it efficient to delegate such a costly task to a bank, through which they all provide funding to the firm. ${ }^{1}$ Within that set-up, borrowing from a single bank is advantageous because it saves on monitoring costs (Diamond (1984)). Borrowing from a single bank, however, may also be advantageous for other reasons. For example, it makes it easier to renegotiate when the firm gets into financial distress (Bulow and Shoven (1978)).

Once a firm has borrowed from a given bank, it has an incentive to borrow from it again. This bank is better positioned to enforce compliance with the terms of the new loan because of the information on the firm it has already learned (Haubrich (1989)). The firm may want to borrow from the same bank again because repeated borrowing gives the bank an opportunity to efficiently tax and subsidise it over time in order to reduce the use of (costly) collateral (Boot and Thakor (1994)). From these perspectives, the longer the relationship a firm has with a bank the lower its incentive to switch banks or initiate multiple relationships.

Relying on a single bank, however, can be costly. The reason is that the bank may develop an information monopoly on the firm because the information it gathers is not easily transferable to other parties. Given that the firm will pay a "lemon's premium" if it approaches another bank, as this bank will question the firm's decision not to seek funding at its original lender, the incumbent bank will be able to extract rents ex post.

Several researchers have studied various implications of the incumbent bank's informational advantage. Greenbaum, Kanatas and Venezia (1989), for example, build on the assumption that the incumbent bank knows more about the firm because the firm borrowed from it in the past to show that if the firm then borrows repeatedly from that bank, the likelihood of it leaving the bank increases as

1 See Bhattacharya and Thakor (1993) and Freixas and Rochet (1997) for a review of the contemporary banking literature. 
their relationship ages. ${ }^{2}$ Sharpe (1990), instead, presents a model where that advantage arises endogenously. An initial situation of competition between symmetrically informed lenders turns into one of asymmetric information once one lender has attracted the business and dealt with the firm for some time. Since both parties rationally anticipate that the firm will be "informationally captured," competition in the banking sector forces initial finance to be offered at a discount to reflect the expected mark-up on future terms of finance. ${ }^{3}$

Anticipating that it will become gradually locked in as the relationship ages, it will be in the firm's interests, as well as in the bank's, to develop arrangements to guarantee that the bank will not extract rents latter on. These arrangements can include an equity investment in the capital of the firm, longterm contracts (von Thadden (1995)), or borrowing simultaneously from the bank and another funding provider, such as the capital markets (Rajan (1992)), trade creditors or another bank.

Regulations in some countries prohibit banks from owning equity stakes in nonfinancial firms. ${ }^{4}$ Agency problems often limit the feasibility of long-term contracts. The little information available on young firms usually makes their access to capital markets infeasible. With respect to trade credit, despite its importance as a funding source, its usefulness to restrict the bank's ability to extract rents is limited because trade creditors usually extend credit only as an ancillary activity to their primary business and not to fund new investments. ${ }^{5}$ Therefore, initiating a second bank lending relationship can be the optimal solution to the potential hold-up problem faced by young firms. As in the Williamsonian "dual-sourcing" theory in industrial organisation, ex ante duplication costs may be more than offset by the protection competition offers to the firm. Note that it may be in the bank's self-interest that the firm initiates a second relationship. ${ }^{6}$ Von Thadden (1992), for example, shows that if incentive compatibility precludes an exclusive monitor from passing future monopoly profits on to the firm through interest reductions, banks will optimally give up exclusivity and offer contracts with duplicated monitoring.

2 Blackwell and Santomero (1982) also argue that long-term relationships may not lead to preferential treatment because when the bank is forced to ration credit it does so first to firms with more elastic demands for loans, regardless of their relationship status.

3 Banking competition limits the incumbent bank's ability to extract rents ex post, but it does not eliminate it because "outside" banks are afraid of a "winner's curse" and bid less aggressively than they would under symmetric information (Broecker (1990)). Competition, however, leads some firms, both good and bad ones, to switch banks when they need added funding (von Thadden (1998)).

4 See Santos (1998) for the regulations in several countries on banks' equity investments in firms.

5 See Elliehausen and Wolken (1993), Petersen and Rajan (1997) and Farinha and Santos (2000) for evidence on the importance of trade credit.

6 The hold-up problem that arises in an exclusive lending relationship is similar to that which arises when customers are deterred from buying specific products from a monopolist supplier because they expect to become locked in and expropriated later on. A common response to this problem has been "dual-sourcing" - monopolists giving away the production technology to a competitor in order to create ex post competition (Shepard (1987) and Farrell and Gallini (1988)). 
Researchers have identified reasons for firms to borrow from multiple banks that are unrelated to the hold-up problem. Bolton and Scharfstein (1996), for example, show that when firms default because they either cannot meet their debt payments or their managers want to divert cash for themselves, borrowing from multiple lenders may be beneficial, particularly for the less risky firms. In doing so, firms incur the costs of defaulting because of a liquidity problem but they reduce management's incentive to default strategically.

Bhattacharya and Chiesa (1995) and von Rheinbaben and Ruckes (1998) consider in turn the role of confidential information in a firm's choice of the number of lenders. Providing information to a lender is beneficial as it allows for a better evaluation but is risky because it may be leaked to the firm's competitors. Therefore, the firm trades off the benefits from competition against the costs of information leakage when it chooses the number of lenders. Yosha (1995) focuses on the signal that the choice of lenders sends to competition. Borrowing from a single lender avoids the disclosure of information that occurs when the firm borrows from multiple lenders, but it leads the firm's competitors to infer that the firm is concealing information and react accordingly. Firms with the most to lose if private information is disclosed borrow from a single lender.

Detragiache, Garella and Guiso (1997) provide a rationale for a firm to seek multiple lenders by considering the cost it incurs when it is denied credit by its bank for reasons that have to do with the bank itself. For example, the bank may be forced to deny credit even to its loyal borrowers because of a temporary liquidity shortage. Given that possibility and the risk of not being able to raise funding from an alternative bank when it approaches it for the first time, then it may be worth starting and maintaining multiple relationships despite the costs that this entails.

Despite the importance attributed in the literature to the single-multiple lender dichotomy, to our knowledge there is no empirical research on a firm's decision to replace a single with multiple bank relationships. Yet this is an important issue in understanding, for example, the importance of exclusive relationships and how the value of these relationships evolves with their duration. It is also an important complement to the growing research on the implications of the number of bank lending relationships chosen by firms. This paper attempts to make a contribution to fill that gap. We use a sample of firms for which we have information on their relationships since the beginning of their life, which allows us to consider the complete history of the firm's relationships with banks. We use duration analysis to investigate why the length of time that elapses from the beginning of an exclusive relationship until its end differs across firms, and to identify the determinants of that difference. We then use conventional regression analysis to study some ex post effects of firms' initiation of multiple relationships.

Our results show that the likelihood of a firm substituting a single with multiple relationships increases with the duration of the single relationship. The investigation into the determinants of that substitution 
shows that, among other things, firms with more growth opportunities and more bank debt are more likely to initiate multiple relationships. It also shows that poorly performing firms and those that more often had bank loans that were past due are also more likely to initiate multiple relationships. These results suggest us two potential explanations for firms' decision to initiate multiple relationships. Firms do that because they want to protect themselves against the future hold-up rents inherent to exclusive relationships, as they are very dependent on banks for funding and have many growth opportunities; alternatively, firms start to borrow from a second bank because the incumbent bank is reluctant to increase its exposure due to the firms' past poor performance and problems in repaying their loans.

The analysis of the ex post effects of the initiation of multiple relationships appears to support the second hypothesis. We find in the years following the initiation of multiple relationships an increase in the firm's bank indebtedness, but we do not detect an increase in its overall indebtedness and in its investment, as one would expect to observe had the firm started multiple relationships because it had many growth opportunities and wanted to protect itself against hold-up rents. In contrast, and compatible with the second hypothesis, we find no improvement in the firm's performance and an increase in its trade credit reliance. Given that trade credit usually comes lower than bank debt in the pecking order, this suggests that the firm is not able to meet its demand for funding in the banking sector even after it initiates multiple relationships. Finally, and still compatible with that hypothesis, we find a continuous decline in the subsequent years in the portion of the firm's bank debt that is provided by the incumbent bank.

The remainder of the paper is organised as follows. The next section presents the empirical literature related to our paper. Section 3 describes our data set. Section 4 presents the method. Section 5 discusses the results and Section 6 concludes.

\section{Related literature}

Since the Petersen and Rajan (1994) study on the implications of the duration of a relationship and on those resulting from borrowing from a single or multiple banks, there have been several studies of these two aspects of firms' relationships with banks. ${ }^{7}$ This literature finds that longer relationships generally improve credit availability, but have a mixed impact on the interest rate charged and the collateral required. Regarding the impact of the single-multiple bank dichotomy, Petersen and Rajan (1994) find that firms with multiple relationships pay higher interest rates and are more credit

7 See Berger and Udell (1995), Blackwell and Winters (1997), Cole (1998), Elsas and Krahnen (1998), Harhoff and Körting (1998a), Angelini, Salvo and Ferri (1998), Degryse and Van Cayseele (1998) and D’Auria, Foglia and Reedtz (1999). See Ongena and Smith (1999a) for a literature review of bank-firm relationships. 
constrained than those with a single relationship. ${ }^{8}$ Other studies on the impact of that dichotomy on the availability of credit, however, find mixed results. ${ }^{9}$

A common problem to studies on the importance of the relationship duration relates to their estimates of duration. Because they rely on firms surveyed only at a given point in time, these studies miss the information on the relationships that have already ended. Moreover, because firms cannot provide information on when the current relationships will end, their duration is therefore "right-censored." Another problem with these studies is that they do not take into account the history of the relationship. For example, they do not consider whether that relationship is or was an exclusive one throughout its entire existence. ${ }^{10}$ These problems are important because, among other things, they make it difficult to understand how the value of a relationship varies with its age and with the number of other relationships the firm might have.

Ongena and Smith (1998) address these issues using a panel of data. In particular, they study the likelihood of the relationship ending given its duration and how that likelihood varies with the number of relationships that the firm has, respectively. They find that long-standing relationships are more likely to end and firms with multiple relationships tend to end a relationship sooner.

The Ongena and Smith study, however, has some problems of its own. Because they rely on firms for which they do not have information prior to the sample period, they are unable to consider the complete history of these firms' relationships and in some cases they cannot identify the beginning of their relationships with banks, thus leading to "left-censored" estimates of duration. These problem are heightened by their reliance on a sample of mature firms (with an average age of 45 years) and therefore with a rich history of bank relationships that the authors cannot account for.

Our paper is closer to that of Ongena and Smith in that we also use duration analysis to study relationships duration. However, there are important differences between the two studies. First, and contrary to them, we are not interested in the duration of a given relationship. We are interest instead in what makes a firm end a single relationship because it wants to borrow from multiple banks. Second, because we want to avoid the problems arising from considering firms that already have a history of relationships at the beginning of the sample period, we consider only firms for which we have their complete history of relationships. This assures us that when the firm starts borrowing from

D’Auria, Foglia and Reedtz (1999), however, find that firms with more relationships pay lower interest rates.

9 Petersen and Rajan (1995), Cole (1998) and Harhoff and Körting (1998a) also find that firms with multiple bank relationships are more credit constrained than those with a single relationship are. Houston and James (1996a, 1996b) find evidence that suggests the opposite, but they rely on listed firms.

10 D'Auria, Foglia and Reedtz (1999) avoid these problems as they consider a panel of firms over the 1987-94 period. However, their estimates of duration are "left-censored" because their information on relationships goes back only to 1985. This problem is heightened by the fact that they rely on a sample of large and medium-sized firms which by 1985 already had by a rich history of bank relationships. 
multiple banks it is the first time it does so. A consequence of this criterion is that we are left with a panel of very young firms. While this has the additional advantage that our results relate to firms for which there is the least information available and therefore the informational theories of banks are most applicable, it has also the disadvantage of our sample being biased towards very young and small firms.

\section{Data}

\subsection{Lending relationships}

Our data source on lending relationships is the monthly reports on credit filed by banks operating in Portugal with the central bank during the period 1980-96. This data source covers virtually all banks operating in the country. The number of banks increased form 14 in 1980 to 43 in 1996. The credit reports detail all of the bank's credit claims vis-à-vis each firm at the end of the month. Because we want to study only bank-firm relationships, we do not consider claims on individuals. Each claim specifies, among other things, the debtor's identity, the amount it owes the bank in the short and long term, and the amount that is past due. ${ }^{11}$ It does not, however, specify the amount and terms of the loans that the bank extended to the firm and which led to the credit claim. For this reason, we cannot use information on such things as the interest rate charged and the collateral required over the life of the firm's relationship with the bank.

Research on the number of firms' bank lending relationships finds that small firms generally have only one relationship and that the average number of relationships increases with the firm's size. ${ }^{12}$ Table 1 shows that these patterns also apply to the Portuguese firms. It also shows that the number of relationships is highly dependent on the firm's age. As firms mature the average number of relationships increases and the number of firms that continue to have a single relationship decreases.

In Table 2, we present stronger evidence of the negative correlation between single relationships and firm age. Note that the fraction of firms that borrow from a single bank decreases very fast with the firm's age, suggesting that most of the firms that initiate multiple relationships do so in the early stages of their life. Table 2, however, is mute about the length of time that elapses from the beginning of an exclusive relationship until its end, that is, until the firm starts to borrow from several banks. This issue is the main focus of our paper.

11 Throughout the paper, short-term claims are defined as those with a maturity shorter than one year and long-term claims as those with a maturity of at least one year.

12 For example, Petersen and Rajan (1994) and Harhoff and Körting (1998a) report that single relationships dominate among small US and German firms respectively. This contrasts with the evidence presented by Detragiache, Garella and Guiso (1997) showing that single relationships are uncommon even among small Italian firms. Ongena and Smith (1999b) report in turn that only a small fraction of large European firms have a single relationship. 
The starting point of our analysis is to investigate, for those firms that borrow for the first time from a single bank, how the likelihood of their starting to borrow from multiple banks varies with the age of the single relationship. We then study some of the ex post effects of that change in the number of relationships. In both cases we analyse how the results vary with a number of factors pertaining to the firm and the bank with which it has a lending relationship. Before presenting these variables, it is important to note that we do not consider in the analysis those firms that borrow for the first time from multiple banks. However, we do not think that this biases our results because, of all the firms that borrow for the first time from banks in the $1980-96$ period only $2 \%$ of them do so from more than one bank.

\subsection{Explanatory variables}

We follow the relationship lending literature and that on the firms' optimal number of creditors to select the explanatory variables for the duration analysis. Even though the latter literature does not derive implications about the timing of a firm's switch from a single to multiple relationships, one would expect that the firms which that literature suggest should borrow from multiple creditors have the most incentive to initiate multiple bank lending relationships earlier. The explanatory variables we consider can be grouped in four sets related to the firm, the bank with which it had the single relationship, the relationship with that bank, and the banking market, respectively. ${ }^{13} \mathrm{We}$ also consider variables to control for other factors that may influence firms' choice of the number of lenders. We do not consider the age of the firm in the duration analysis, however, because this variable is highly correlated with our dependent variable.

We attempt to capture with the set of variables related to the firm several factors that may play a role in its decision to initiate multiple relationships. First, we consider its growth opportunities, which we proxy by the firm's size, growth and investments, as an indication of its need for funding. ${ }^{14}$ Second, we account for the firm's risk, which we proxy by the firm's profitability and solvency. Third, we consider the funding provided by its main sources of funding, namely the bank, trade creditors and insiders (firm shareholders and other associated firms). Fourth, we use the firm's liquidity as a measure of its "financial slack." Fifth, we use a dummy variable to control whether the firm is independent or part of a conglomerate. Finally, we use the ratio of the firm's tangible assets to its debt as a measure of its ability to pledge collateral and its intangible assets as a measure of its opaqueness.

13 Our source for firms' balance sheet data is the balance sheet survey conducted by the Bank of Portugal on a yearly basis since 1986. Our sources for bank balance sheet data and the regional number of bank branches are the publications of the Portuguese Bankers Association.

14 The results in the paper are for the case where the firm's size and growth are measured by its sales. We obtained similar results when we measured those variables by the firm's number of employees. 
With respect to the bank with which the firm has the single relationship, following the diversification argument of Detragiache, Garella and Guiso (1997) for firms to borrow from multiple banks, we include variables intended to capture the bank's lending capacity. These are the bank's size, growth, liquidity, profitability and the fraction of its assets in loans.

Our third group of variables relates to the single relationship that the firm has before it initiates multiple relationships. ${ }^{15}$ In line with von Thadden's (1995) suggestion that firms can protect themselves from ex post rents extraction attempts by making use of long-term contracts, we include the long-term portion of the firm's bank debt to account for its ability to access long-term financing. We include a dummy to indicate if the firm has past due loans from that bank. We account for the risk exposure regulation by considering the ratio of the amount the firm owes the bank over the bank's capital. ${ }^{16}$ Following von Thadden's (1998) argument that in the presence of competition some firms may react to an incumbent bank's attempt to extract rents by switching banks, we consider the number of times the firm switched banks in the past.

With respect to the banking market group, we consider variables that attempt to capture the competition among banks in the market relevant to the firm. As Petersen and Rajan (1995) show, competition is detrimental to relationship lending because it makes it more difficult for the bank to carry out intertemporal subsidisation. ${ }^{17}$ We proxy banking competition by the number of banks in the region where the firm is located and we control if the firm's single relationship is with a local bank. ${ }^{18}$

Finally, we consider a set of variables to control for other factors that may influence a firm's choice of the number of lenders. We include a bank age dummy to control whether the incumbent bank is an old or a new bank $;^{19}$ economic activity dummies to control for factors that are specific to the various sectors of activity; ${ }^{20}$ and time dummies to control for time-varying effects such as macroeconomic conditions.

15 We do not include a dummy to indicate if the incumbent bank owns an equity stake in the firm because that happens with only two of the firms in our sample.

16 This regulation requires banks to limit their exposure to any single borrower to $25 \%$ of their own funds. We do not expect it to be binding for these firms because they are all small firms.

17 Boot and Thakor (forthcoming), however, show in a different set-up that an increase in competition encourages banks to customise services and leads to an increase in relationship lending, but as competition keeps increasing that response is no longer profitable and relationship lending decreases.

18 Here we follow Hannan (1991), who argues that the relevant banking market for small firms is formed by the banks in the region where the firm is headquartered.

19 We define the banks operating at the beginning of our sample period to be old and those created since then to be new.

20 Anecdotal evidence suggests banks often take into account the firm's sector of activity in their decision to extend credit to the firm. The results presented in the paper were estimated without these dummies. We did not detect any significant changes, however, when we included the dummies. 


\subsection{Sample}

As mentioned above, to avoid the problems of left-censoring, we consider only firms born after 1980 that borrow for the first time from a single bank. We have balance sheet data for every year from the time they first borrow until they initiate multiple relationships or the end of the sample period (1996) for 1,577 firms. Of these firms, 870 borrow from a single bank throughout the entire sample period (censored observations) and 707 start to borrow from multiple banks after they have had a single relationship lasting on average two years. The median duration of these single relationships is two years. Note, however, that this duration is "right-censored" because it does not take into account those firms in the sample (870) that still have a single relationship at the end of the sample period. Once this is considered and duration is adjusted for "right-censoring" the median of the single relationship duration becomes five years.

Of the 707 firms that initiate multiple relationships, 512 did not switch from their original lender and 195 switched banks before they started to borrow from several banks. Table 3 compares these two sets of firms at the time immediately before the firm substitutes a single relationship with multiple relationships. Firms that switch banks initiate multiple relationships on average 7.5 months later than those that do not switch banks beforehand. Note, though, that at the time the latter initiate multiple relationships they are younger but appear to be more dynamic. They are growing faster, have less liquidity and are more indebted vis-à-vis both banks, trade creditors and firm insiders (insider debt is defined as the sum of loans extended by the firm's shareholders and associated firms). Finally, it is worth noting that trade credit is the most important source of external funding for both sets of firms. It appears ahead of insider debt and bank debt.

Following von Thadden (1998), who argues that firms may react to a bank's attempt to extract rents by switching banks, we compare in Table 4 firms that initiate multiple relationships with those that switch banks. ${ }^{21}$ The statistics in the table show that these are two quite different sets of firms. Firms that initiate multiple relationships are younger, more dynamic, but less profitable. They are growing faster, have less liquidity, are more indebted vis-à-vis both banks and trade creditors and have more longterm bank loans. These results seem to suggest that the causes that lead firms to end a single relationship by switching banks are different from those that lead banks to end a single relationship by initiating multiple relationships.

21 The former are measured just before they initiate multiple relationships and the latter are measured just before they first switch banks. 


\section{Method}

\subsection{Duration analysis}

We use duration analysis to analyse, for firms starting out with a single relationship, the time that elapses from the beginning of that relationship until the firm starts to borrow from multiple banks. The term "spell" in duration analysis is used as a catch-all for the different duration variables that may be measured. The length of a spell can be represented by a continuous random variable, $T$, with a density function $f(t)$ where $t$ is a realisation of $T$. The hazard function gives us the rate at which spells are completed after duration $t$, given that they lasted at least until $t$. It can be defined as

$$
\lambda(t)=\lim _{\Delta t \rightarrow 0} \frac{P(t \leq T<t+\Delta t \mid T \geq t)}{\Delta t},
$$

or alternatively in terms of the distribution and probability density functions of $T:{ }^{22}$

$$
\lambda(t)=\frac{f(t)}{1-F(t)}=\frac{f(t)}{S(t)}
$$

where $S(t)$ is defined as the survivor function. It gives us the probability that the spell duration lasts until $t$.

The hazard function does not add any information to $f(t)$, but it is useful because it provides a straightforward interpretation of the distribution. When a hazard function has a positive slope (negative slope), it is said to have positive (negative) duration dependence, that is, the likelihood that the spell ends at time $t$, conditional upon duration until $t$, increases (decreases) in $t$.

\subsubsection{Explanatory variables and the hazard function}

Parametric models of duration, which are akin to the conventional regression models, embody specific assumptions about the distribution of duration. In parametric analysis the choice among the various models is made on the basis of the specification chosen for the distribution, the Weibull being one of the most frequently used in the literature. Its hazard function is ${ }^{23}$

$$
\lambda(t)=\lambda p(\lambda t)^{p-1}
$$

When $p>1(p<1)$, the Weibull hazard function has positive (negative) duration dependence. The effect of explanatory variables on the hazard function can be considered by assuming

$$
\lambda_{i}=e^{-\beta^{\prime} x_{i}}
$$

22 Lancaster (1990). 
This is equivalent to a change in the units of measurement on the time axis. The coefficients for the explanatory variables can be estimated by maximising the likelihood function, which when it incorporates the relevant probabilities for right-censored observations can be written as

$$
\ln L=\sum_{i}\left[\delta_{i} \ln f\left(w_{i}\right)+\left(1-\delta_{i}\right) \ln S\left(w_{i}\right)\right]
$$

where $\delta_{i}$ takes the value 1 if the spell is completed and 0 if it is censored, and $w_{i}$ results from a convenient change of variable:

$$
w_{i}=p \ln \left(\lambda_{i} t_{i}\right)=p\left(\ln t_{i}-\beta^{\prime} x_{i}\right)
$$

With the Weibull distribution, the sign of the coefficients suggests the direction of the effect of the explanatory variable on the hazard function. In these cases we can also get a regression-like interpretation of the magnitudes of the coefficients because we have:

$$
E\left[t \mid x_{i}\right]=\exp \left(p \beta^{\prime} x_{i}\right)
$$

Thus, $\beta_{k}$ is a multiple of the derivative of this conditional mean.

Parametric models, however, impose specific assumptions on the distribution of duration data. For this reason, semi-parametric models have proven useful to analyse duration data because they impose fewer restrictions. Cox's approach to the proportional hazard model, for example, assumes that the hazard rate may be written as the product of the "baseline" hazard function and a non-negative function

$$
\lambda(t, x, \beta)=\lambda_{0}(t) \phi(x, \beta) .
$$

The Cox approach provides a method of estimating $\beta$ without requiring estimation of $\lambda_{0}$. Therefore, it is not subject to the bias that could be induced by specifying an incorrect form for the baseline hazard function. However, as no baseline hazard function is assumed, the estimator does not reflect the information that the individual $i$ has survived until $t_{\mathrm{i}}$.

Most estimators have been developed under the assumption that the explanatory variables do not vary with time or that the time path of these variables does not affect the likelihood of exiting. Despite the fact that most relevant variables change with duration, in some cases they change at a slower pace than a typical duration. For that reason, they are often treated as if they were constant. ${ }^{24}$ As we did not expect this was the case for most variables in our sample period, we relax that assumption by incorporating time-varying explanatory variables in the duration model. Different values of these

\footnotetext{
23 The exponential distribution can be derived from the Weibull distribution by assuming $p=1$.

24 Lancaster (1990), p. 21.
} 
variables are provided for each interval between $t=0$ and $t=t_{i}$, the terminal point at which exit or censoring takes place. $^{25}$

\subsection{Regression analysis}

To analyse the performance of firms after they start borrowing from multiple banks we followed the firms in our sample during several periods after the change. In this case the variables of interest were the investment rate, debt ratios (total, bank, insiders and trade creditors) and profitability. The analysis was structured along the following lines. Let $Y_{i t}$ be the variable of interest of firm $i$ in period $t$. The general model was then:

$$
Y_{i t}=\alpha_{1} \text { Multiple Banks } s_{i t}+\alpha_{2} \text { Switch Banks }{ }_{i t}+\mathrm{BX}_{i t}+\theta_{i}+\lambda_{t}+\varepsilon_{i t}
$$

where Multiple Banks ${ }_{i t}$ is a dummy variable which takes the value 1 from the moment the firm starts to borrow from more than one bank until the end of the sample period and 0 otherwise. The variable Switch Banks $s_{i t}$ is a dummy that takes the value 1 from the moment the firm switches banks for the first time until the end of the sample period and 0 otherwise. We are primarily interested in estimating $\alpha_{1}$ and $\alpha_{2}$. However, we need to control for other firm characteristics expected to be correlated with the dependent variables. This was done in two ways, first by including a set of observed firm variables (such as firm size and age) represented by $X_{i t}$. We also took advantage of the panel nature of the data by estimating a fixed-effects model in order to account for unobserved firm-specific time-constant factors. The coefficients $\theta_{\mathrm{i}}$ in the model capture this heterogeneity. The effect of time-varying economy-wide conditions was also taken into account, by including a set of time dummy variables. The $\lambda_{t}$ in the model represents the time effects. Finally, $\varepsilon_{i t}$ is the error term of the regression.

With our data the random-effects estimator was clearly rejected in favour of the fixed-effects model. The random-effects model assumes that the individual effects are uncorrelated with the other regressors. Under the alternative hypothesis this estimator is not consistent. The procedure suggested by Hausman (1978) may be used to test for orthogonality of the random effects and the regressors. Large values of the Hausman statistic argue in favour of the fixed over the random-effects estimator. F-statistics were also computed in order to test for the overall significance of both firm and time dummies in the fixed-effects model.

25 See Lancaster (1990), p. 23, for a discussion of some of the issues associated with these models. 


\section{Results}

As mentioned above, we want to find out, for the firms that borrow for the first time from a single bank, the likelihood of their starting to borrow from multiple banks as their single bank relationships mature and the determinants of that likelihood. In addition, we want to investigate the implications for a firm of substituting a single bank relationship with relationships with multiple banks.

\subsection{Results of the duration analysis}

We start by estimating several parametric and semi-parametric models of duration to study the firms' likelihood of initiating multiple relationships. Recall that as we consider only firms for which we have information on their bank lending relationships since the beginning of their life, we avoid the problem of left-censored observations. Note though that we are still left with the usually unavoidable problem of right-censored observations, which can appropriately be taken into account in the estimation.

Table 5 presents the results of the estimation of the model where the dependent variable is the duration of the single relationship measured from its beginning until the firm initiates multiple relationships (or censoring). These results were obtained using a fully parameterised specification for the baseline hazard (Weibull distribution) and assuming that the path of the explanatory variables does not affect the probability of firms' initiating multiple relationships. The explanatory variables were measured at the time just before the change in the number of relationships (or censoring) occurs.

The results show that the likelihood of a firm substituting a single relationship with multiple relationships increases with the duration of the single relationship, as a unilateral test to the null hypothesis $p \leq 1$ is rejected for the conventional significance levels in all three models. They also show that the estimated median duration of single relationships that end when firms initiate multiple relationships is almost five years.

The models in Table 5 show that the likelihood of changing to multiple relationships increases with the firm's size, growth and investments. That likelihood is also larger for firms with more bank debt and for those that had past due bank loans more often during the time they had a single relationship. Firms that belong to conglomerates are also more likely to replace a single relationship with multiple relationships, but those with more liquid assets are less likely to do so. Finally, note that even though the bank and the banking market variables are not individually statistically significant (with the exception of the bank location dummy, but only at the $10 \%$ level of significance, and the risk exposure, but only in one of the models) as a group each of these two sets of variables is statistically significantly different from zero as the likelihood ratio indicates. 


\subsection{Robustness checks}

\subsubsection{The Weibull assumption on the distribution of duration}

To evaluate the sensitivity of the results presented in Table 5 to the choice of the underlying distribution, the models were re-estimated using the Cox approach to the proportional hazard model. This is a semi-parametric model in that it only needs minimal assumptions about the underlying distribution. The results of the Cox approach are reported in Table 6. They provide similar evidence on the determinants of the likelihood of a firm substituting a single with multiple bank lending relationships. $^{26}$

\subsubsection{The assumption on the time path of the explanatory variables}

To assess the assumption that the explanatory variables do not vary with time or that their time path does not affect the likelihood of changing from single to multiple relationships, we re-estimated the models presented in Table 5, this time using time-varying explanatory variables. Different values of those variables for each year between the beginning of the relationship and the terminal observation were included in the estimations.

The results with time-varying explanatory variables are reported in Table 7. In general they support our initial results. There are, however, two differences worth noting here. The firm's profitability and the number of times it switched banks before it initiated multiple relationships are now statistically significantly different from zero. Because the former is positive it suggests more profitable firms are less likely to replace single relationships with multiple relationships. Because the coefficient on the number of switches is negative, it suggests that firms that switch banks more often are more likely to start multiple relationships.

\subsubsection{The exogeneity assumption of the variable "number of switches"}

As discussed above, a possible reason for firms to initiate multiple relationships is to avert the ex post rents they would pay if they were to maintain a single relationship. Alternatively, the firm may choose to maintain a single relationship and switch banks in response to an incumbent bank's attempt to extract rents. If this were to be the case, then there would be some substitutability between bank switches and initiations of multiple relationships. In addition, the assumption of exogeneity of the explanatory variable "number of switches" would not hold, and consequently the quality of our estimations would be influenced.

Our results do not seem to support the substitutability hypothesis, as we find that firms that switch banks are more likely to initiate multiple relationships. As a further check on the robustness of our 
results, we re-estimated our models excluding from our sample all the firms that switched banks before they initiated multiple relationships. The results are reported in Table 8. They confirm the results presented in Table 7, which were obtained with all the firms in the sample. The main difference relates to trade credit, which is now statistically significantly different from zero.

\subsubsection{Distinguishing switches from initiations of multiple relationships}

Finally, we evaluate the sensitivity of our results to the procedure we used to distinguish switches between banks from initiations of multiple relationships. As mentioned above, our data source contains only the amounts that a firm owes each bank at the end of every month during the sample period. In some cases it is difficult to distinguish a switch from an initiation of multiple relationships based on that information. For example, when a firm owes money for the first time to two banks, one of which is its old lender, it does not necessarily mean that it has started multiple relationships. It could be that the firm has switched banks but still owes money to its original lender. When that occurs closer to the end of the sample period it becomes difficult to distinguish the two possibilities.

We considered several variants to the criteria we used to distinguish switches from initiations of multiple relationships. ${ }^{27}$ In all cases we obtained results similar to those presented in Table 7 concerning both the likelihood of firms with single relationships starting multiple relationships, the median estimation of single relationships and the impact of the firm-characteristic variables on that likelihood. We found, however, some differences on the significance of certain bank-characteristic variables.

Table 9 presents the results for one of the variants that we studied. It relates to the case where we excluded all the firms that started borrowing from a second bank less than 12 months before the end of the sample period (57 firms), and a subset of the firms we had considered to have switched banks. This subset included the firms that started to borrow from a second bank and did not increase their indebtedness with the former bank during the subsequent 12-month period, but started to borrow again from the first bank during the second subsequent 12-month period (10 firms). The results obtained with this sample are similar to those we got with our original sample. There is only one difference. It relates to the firms' investments: while it continues to carry the same sign, it is not statistically significant any more.

After identifying the first month a firm owes money to more than one bank, say $t_{0}$, we considered the following criteria to decide whether the firm switched banks or started multiple relationships at that time. If at $t_{0}$ the firm starts to owe money to three or more banks we considered as having started multiple relationships at $t_{0}$. If it starts to owe money to two banks and in the twelve subsequent months it increased the amount it owed the incumbent bank at $t_{0}$ by more than 


\subsection{A possible interpretation of the results}

What do the results we unveil have to say regarding the various hypotheses suggested in the literature regarding a firm's decision to borrow from multiple banks rather than a single bank? They do not support the hypothesis that firms initiate multiple relationships because they want to diversify the risk of being denied credit for reasons that have to do with their bank, as we find that bank variables do not influence firms' decisions to start multiple relationships. They do not support either of the opposing views in the literature regarding the impact of bank competition on relationship lending, as the variables we consider as proxies for competition are generally not statistically different from zero. ${ }^{28}$ Our results also do not appear to support the hypothesis that switching banks is a substitutable device to initiating multiple relationships, as we find that firms that switch banks more often also initiate multiple relationships earlier.

Our results' support for the hypothesis that firms initiate multiple relationships in order to avert the hold-up rents associated with an exclusive relationship is mixed, thus casting some doubt on that explanation. The relationship lending literature suggests that as a firm's relationship with a single bank gets older, the firm will become increasingly locked in. Moreover, the more dependent the firm is on that bank for funding the more growth opportunities it has, and the more opaque its assets are the larger will be in the future the costs of becoming locked in and therefore the higher the firm's incentives to initiate multiple relationships earlier.

We do find that the likelihood of a firm substituting a single with multiple relationships increases with the duration of the single relationship and that such a likelihood is larger for firms with more bank debt, less liquidity and more growth opportunities. ${ }^{29}$ However, we do not find the conditional likelihood of initiating multiple relationships to be higher for firms with more intangible assets, and therefore more opaque assets, for firms with less trade credit and insider debt, and therefore more bank dependent, and for firms with less capacity to pledge collateral. The availability of collateral makes the information specific to the firm less valuable, as the firm can use the collateral to raise funding.

There are two other results that also cast some doubt on the concern of becoming locked in as the reason for initiating multiple relationships. More profitable firms are less likely to substitute a single with multiple relationships and firms that have had past due loans more often are more likely to

$25 \%$ then we considered that the firm started multiple relationships at $t_{0}$. Otherwise we assumed that what happened at $t_{0}$ was a switch rather than the beginning of multiple relationships.

28

Apart from the debatable capability of those variables to measure banking competition, it is also worth noting that these are exactly the two variables with the lowest variability (Tables 2 and 3), which raises some questions concerning their performance.

29

Recall that we proxy growth opportunities by the firm size, growth rate and investments. 
initiate multiple relationships. ${ }^{30}$ These two results in fact suggest an alternative reason for firms to initiate multiple relationships: the incumbent bank may not be willing to increase its credit exposure to those firms because of their poor performance in the past.

A study of the ex post effects of the substitution of single with multiple relationships can help us ascertain the plausibility of those hypotheses. If a firm initiates multiple relationships because it has many growth opportunities and therefore is concerned with the future costs of becoming locked in, then we would expect it to borrow a significant amount from the new bank in order to promote competition with the incumbent bank and to implement some of its growth opportunities, leading, for example, to an increase in its indebtedness and investment. In contrast, if the firm initiates multiple relationships because the incumbent bank refuses to increase its exposure to the firm due to its past poor performance, then we should not observe an increase in the firm's investment and we should observe an increase in the firm's reliance on the funding sources, such as trade credit, that come lower than bank debt in the pecking order. Moreover, in this case we should also not observe an improvement in the firm's performance, as this would mean that the incumbent bank systematically misevaluated the firms with which it had an exclusive relationship.

\section{$5.4 \quad$ Ex post effects}

We start by studying the number of relationships that firms choose to maintain in each of the four subsequent years after they start to borrow from multiple banks. The results are reported in Table 10 . They show that during that period of time the majority of firms borrow from only two banks. We ascertain the importance of the new relationship by studying the share of bank debt provided by the incumbent bank in each of those four years. As the results in table 10 show, the share of bank debt provided by the incumbent bank decreases to $63 \%$ in the year the firm starts to borrow from a second bank and it reaches $50 \% 3$ years latter. These results suggest that the second relationship is an important one from its very beginning.

We then use regression analysis to identify some effects of the firm's substitution of a single with multiple relationships on investment, debt ratios and profitability. ${ }^{31}$ The results obtained with the fixed-effects estimator are reported in Table 11. They seem to confirm that firms do not initiate multiple relationships because they are planing to implement many growth opportunities and therefore

Our result that poorly performing firms, that is firms with lower profitability and those that had past-due loans more often, are more likely to initiate multiple relationships is consistent with Harhoff and Körting (1998b) finding based on a sample of German firms that those which experience financial distress are more likely to increase their number of bank relationships. They are also consistent with the evidence in Foglia, Laviola, Reedtz.(1998) based on Italian firms that those which have more bank relationships are more likely to fail in the near future.

31 The reported F-statistics suggest a statistically significant improvement in the model fit when the regression includes firm-specific effects. The value of the Hausman statistic on the hypothesis of orthogonality between the individual effects and the regressors is rejected, thus indicating that one should chose the fixed-effects estimator. 
want to protect themselves against the hold-up rents inherent to a single relationship, as we do not find an increase in firms' investments and indebtedness in the years after they started to borrow from multiple banks.

The ex post results, in contrast, appear to support the hypothesis that it is the incumbent bank's potential reluctance to increase its exposure to the firm because of its poor past performance that leads it to start borrowing from another bank. Despite the fact that after initiating multiple relationships the firm increases its usage of bank debt, it also increases its reliance on trade credit. ${ }^{32}$ Given that trade credit usually comes lower than bank debt in the pecking order, this suggests that the firm is not able to meet its demand for funding in the banking sector even after it initiates multiple relationships. Still compatible with that assertion, we find no improvement in the firm's performance afterwards and we also find a continuous decline in the subsequent years in the portion of the firm's bank debt that is provided by the incumbent bank (Table 10).

\section{Final remarks}

The empirical evidence presented in this paper on bank lending relationships shows that nearly all firms borrow for the first time from one bank and that the majority of them continue to do so for many years. Some firms, however, choose to borrow from multiple banks after some time. Duration analysis of a firm's decision to substitute a single relationship with multiple relationships shows that the older the single relationship the more likely it is for firms to start multiple relationships.

Our investigation into the determinants of the conditional likelihood of initiating multiple relationships finds that the incumbent bank's characteristics and those of the banking market where the firm is headquartered do not play a role in the firm's decision to substitute a single with multiple relationships. In contrast we find that firms with more growth opportunities, more bank debt and less liquidity are more likely to initiate multiple relationships. We also find that firms with lower profitability and those that more often have bank loans that were past due are more likely to initiate multiple relationships.

The analysis of the ex post effects of the initiation of multiple relationships shows an increase in the firm's bank debt, but no increase in its overall indebtedness and investment. That analysis also shows an increase in the firm's reliance on trade credit, a reduction in the importance of the incumbent bank as a provider of funding and no improvement in the firm's performance. These results led us to argue that a potential unwillingness by the incumbent bank to increase its exposure to the firm because of its

32 It is worth noting here that Houston and James (1996a) also find that firms in their sample increase significantly their use of bank debt once they substitute a single with multiple banking relationships. Their results, however, report to a sample of listed firms and thus with well-established track records. 
past poor performance appears to explain better the firms' decision to initiate multiple relationships than the hypothesis that they do so to protect themselves against the hold-up rents inherent to exclusive relationships because they are dependent on banks for funding and have many growth opportunities.

Finally, it is worth noting that our results, as other research has shown, suggest that there is value in a firm's relationship with a bank. Our result that exclusive bank relationships with firms that perform well generally last longer than exclusive relationships with poorly performing firms suggests that a relationship is more valuable to the former firms than to the latter ones. But even the latter firms appear to value their relationships with the incumbent bank because the majority of them continue to borrow from it afterwards. We find, for example, that one year after the initiation of multiple relationships $75 \%$ of the firms still borrow from the bank with which they had an exclusive relationship, and two years later $54 \%$ of them still borrow from that bank. Evidence on the existence of value in a bank-firm relationship is important because it suggests that the substitutability of these relationships depends on their duration, in which case changes to the banking sector that perturb the established relationships, such as those resulting from bank mergers and acquisitions, will have implications far beyond the short term. 


\section{Tables}

Table 1 Number of bank lending relationships at the end of 1995 (relative frequencies)

Table 2 Number of bank lending relationships given the age of the firm

Table 3 Firms that borrow for the first time from a single bank but later initiate multiple relationships

Table 4 Firms that borrow for the first time from a single bank but later either switch banks or initiate multiple relationships

Table 5 Duration of single relationships: full parametric models (Weibull distribution) 26

Table 6 Duration of single relationships: semi-parametric model (Cox model)

Table 7 Duration of single relationships: parametric models (Weibull distribution) with time-varying explanatory variables

Table 8 Duration of single relationships for firms that do not switch banks before they start multiple relationships: parametric models (Weibull distribution) with time-varying explanatory variables

Table 9 Duration of single relationships: parametric models (Weibull distribution) with time-varying explanatory variables

Table 10 Importance of the relationship with the incumbent bank after the firm changes from single to multiple relationships

Table 11 Effects of firms' substitution of single with multiple relationships. Models estimated with fixed effects 
Table 1

Number of bank lending relationships at the end of 1995 (relative frequencies) ${ }^{1}$

\begin{tabular}{|l|c|c|c|c|c|}
\hline \multirow{2}{*}{$\begin{array}{c}\text { Number of } \\
\text { relationships }\end{array}$} & \multirow{2}{*}{ Total sample } & \multicolumn{2}{|c|}{ Relationships by firm size } & \multicolumn{2}{c|}{ Relationships by firm age } \\
\cline { 3 - 6 } & & $<\mathbf{1 0}$ employees & $<\mathbf{1 0 0}$ employees & < 5 years & $<\mathbf{1 0}$ years \\
\hline 1 & 57.30 & 69.60 & 58.80 & 69.60 & 64.10 \\
\hline 2 & 22.70 & 20.50 & 22.90 & 20.50 & 22.10 \\
\hline 3 & 9.70 & 6.50 & 9.60 & 6.30 & 8.00 \\
\hline 4 & 4.60 & 1.90 & 4.30 & 2.10 & 3.00 \\
\hline 5 & 2.50 & 0.80 & 2.20 & 0.80 & 1.40 \\
\hline 6 & 1.30 & 0.40 & 1.10 & 0.30 & 0.60 \\
\hline 7 & 0.80 & 0.10 & 0.60 & 0.20 & 0.30 \\
\hline 8 & 0.50 & 0.00 & 0.30 & 0.10 & 0.10 \\
\hline 9 & 0.30 & 0.00 & 0.20 & 0.10 & 0.10 \\
\hline 10 & 0.20 & 0.00 & 0.10 & 0.10 & 0.10 \\
\hline$>10$ & 0.30 & 0.00 & 0.10 & 0.00 & 0.10 \\
\hline Mean & 1.87 & 1.46 & 1.78 & 1.47 & 1.61 \\
\hline Median & 1 & 1 & 1 & 1 & 1 \\
\hline Mode & 1 & 1 & 1 & 1 & 1 \\
\hline $\mathrm{N}^{2}$ & 54,182 & 31,926 & 52,203 & 13,436 & 29,109 \\
\hline 1
\end{tabular}

${ }^{1}$ The statistics presented in the table relate to a sample of 54,182 firms. These are the firms in the credit reports for which we have information on their age and on their size as measured by the number of employees. Data on the number of employees is from Quadros de Pessoal, a Ministry of Employment publication. ${ }^{2}$ Number of firms. 
Table 2

Number of bank lending relationships given the age of the firm ${ }^{1}$

\begin{tabular}{|c|c|c|c|c|c|c|}
\hline $\begin{array}{l}\text { Age of } \\
\text { the firm }\end{array}$ & $\begin{array}{c}\text { Number of } \\
\text { firms }\end{array}$ & Mean & Median & Mode & $\begin{array}{l}\text { Coefficient of } \\
\text { variation }\end{array}$ & $\begin{array}{c}\% \text { of firms } \\
\text { with a single } \\
\text { relationship }\end{array}$ \\
\hline 0 & 18,046 & 1.15 & 1 & 1 & 0.40 & 87.93 \\
\hline 1 & 50,383 & 1.28 & 1 & 1 & 0.51 & 79.11 \\
\hline 2 & 59,676 & 1.40 & 1 & 1 & 0.58 & 72.82 \\
\hline 3 & 60,479 & 1.50 & 1 & 1 & 0.63 & 68.33 \\
\hline 4 & 57,916 & 1.58 & 1 & 1 & 0.66 & 65.11 \\
\hline 5 & 54,506 & 1.64 & 1 & 1 & 0.68 & 62.90 \\
\hline 6 & 50,805 & 1.69 & 1 & 1 & 0.69 & 61.04 \\
\hline 7 & 46,248 & 1.75 & 1 & 1 & 0.71 & 59.48 \\
\hline 8 & 41,852 & 1.79 & 1 & 1 & 0.72 & 58.20 \\
\hline 9 & 37,359 & 1.83 & 1 & 1 & 0.73 & 56.92 \\
\hline 10 & 33,636 & 1.87 & 1 & 1 & 0.74 & 55.93 \\
\hline 11 & 30,259 & 1.91 & 1 & 1 & 0.75 & 55.61 \\
\hline 12 & 28,067 & 1.93 & 1 & 1 & 0.76 & 54.86 \\
\hline 13 & 26,014 & 1.95 & 1 & 1 & 0.77 & 54.47 \\
\hline 14 & 24,543 & 1.99 & 1 & 1 & 0.77 & 53.80 \\
\hline 15 & 22,211 & 2.01 & 1 & 1 & 0.78 & 53.07 \\
\hline 16 & 19,648 & 2.04 & 1 & 1 & 0.78 & 52.51 \\
\hline 17 & 17,498 & 2.07 & 1 & 1 & 0.79 & 52.33 \\
\hline 18 & 15,681 & 2.12 & 1 & 1 & 0.80 & 51.71 \\
\hline 19 & 13,778 & 2.15 & 1 & 1 & 0.81 & 51.27 \\
\hline 20 & 11,928 & 2.18 & 1 & 1 & 0.82 & 51.00 \\
\hline 21 & 10,607 & 2.21 & 1 & 1 & 0.82 & 50.79 \\
\hline 22 & 9,787 & 2.22 & 1 & 1 & 0.83 & 50.99 \\
\hline 23 & 9,058 & 2.22 & 1 & 1 & 0.83 & 50.42 \\
\hline 24 & 8,244 & 2.23 & 1 & 1 & 0.84 & 51.16 \\
\hline 25 & 7,529 & 2.25 & 1 & 1 & 0.84 & 50.72 \\
\hline$>25$ & 100,469 & 2.49 & 2 & 1 & 0.86 & 47.20 \\
\hline
\end{tabular}

${ }^{1}$ The statistics presented in the table relate to a panel covering the years 1980-96 and a set of 127,743 firms. These are the firms in the credit files for which we have information on their age. 
Table 3

Firms that borrow for the first time from a single bank but later initiate multiple relationships

\begin{tabular}{|c|c|c|c|c|c|}
\hline \multirow{2}{*}{$\begin{array}{c}\text { Variables } \\
\text { Firm } \\
\end{array}$} & \multicolumn{2}{|c|}{$\begin{array}{l}\text { Firms that did not } \\
\text { switch banks before } \\
\text { initiating multiple } \\
\text { relationships } \\
(512 \text { firms })^{1}\end{array}$} & \multicolumn{2}{|c|}{$\begin{array}{l}\text { Firms that switched } \\
\text { banks before initiating } \\
\text { multiple relationships } \\
(195 \text { firms })^{1}\end{array}$} & \multirow[t]{2}{*}{$\begin{array}{l}\text { t-test for } \\
\text { difference } \\
\text { of means }\end{array}$} \\
\hline & Mean & $\mathrm{CV}^{3}$ & Mean & $\mathrm{CV}^{3}$ & \\
\hline Age (years) & 3.92 & 0.70 & 4.45 & 0.64 & $2.25 * *$ \\
\hline Conglomerate dummy ${ }^{4}$ & 0.03 & 5.40 & 0.03 & 6.19 & -0.52 \\
\hline Size (sales) $)^{5}$ & 0.67 & 8.56 & 0.13 & 3.25 & -1.30 \\
\hline Size (employees) & 58.83 & 4.75 & 41.78 & 2.99 & -0.83 \\
\hline Sales growth $(\%)$ & 50.73 & 2.42 & 32.62 & 3.09 & $-1.84 *$ \\
\hline Liquidity/assets & 0.09 & 1.34 & 0.12 & 1.26 & $2.17 * *$ \\
\hline Intangibles/assets & 0.01 & 4.08 & 0.01 & 4.13 & -0.44 \\
\hline Tangibles/total debt & 0.53 & 1.58 & 0.55 & 1.11 & 0.36 \\
\hline Investments/assets & 0.09 & 1.52 & 0.10 & 1.26 & 0.27 \\
\hline Investments/sales & 0.09 & 1.95 & 0.11 & 2.97 & 1.31 \\
\hline $\begin{array}{l}\text { Investments/ } \\
\text { (intangibles + tangibles) }\end{array}$ & 0.31 & 1.07 & 0.33 & 1.03 & 0.50 \\
\hline Cash flow/assets & 0.10 & 1.11 & 0.11 & 1.01 & $1.68^{*}$ \\
\hline Equity/assets & 0.24 & 0.75 & 0.28 & 0.70 & $2.25 * *$ \\
\hline Bank loans/assets & 0.12 & 1.29 & 0.09 & 1.47 & $-2.46 * * *$ \\
\hline Trade credit/assets & 0.29 & 0.74 & 0.26 & 0.77 & $-1.80 *$ \\
\hline Insider loans/assets ${ }^{6}$ & 0.18 & 1.22 & 0.17 & 1.20 & -0.58 \\
\hline \multicolumn{6}{|l|}{ Bank } \\
\hline Size (assets) ${ }^{5}$ & 572.31 & 0.73 & 591.92 & 0.87 & 0.53 \\
\hline Growth of assets (\%) & 15.05 & 2.55 & 19.62 & 2.04 & 1.40 \\
\hline Total lending/assets & 0.53 & 0.22 & 0.55 & 0.24 & $1.95^{*}$ \\
\hline Liquidity/assets & 0.16 & 0.83 & 0.15 & 0.88 & -1.35 \\
\hline Profits/assets & 0.01 & 0.89 & 0.01 & 1.00 & -0.50 \\
\hline \multicolumn{6}{|l|}{ Bank-firm relationship } \\
\hline Number of relationships $^{7}$ & 1 & - & 2.13 & 0.18 & - \\
\hline Single relationship duration (months) & 22.00 & 0.73 & 29.46 & 0.51 & $5.46^{* * *}$ \\
\hline Bank long-term loans/bank debt & 0.11 & 2.63 & 0.08 & 3.20 & -1.38 \\
\hline Past due loans dummy ${ }^{8}$ & 0.02 & 6.75 & 0.02 & 8.01 & -0.52 \\
\hline Past due loans (accumulated) dummy ${ }^{9}$ & 0.07 & 3.75 & 0.06 & 4.10 & -0.49 \\
\hline Risk exposure $^{10}$ & 0.001 & 7.17 & 0.0004 & 5.49 & -1.24 \\
\hline \multicolumn{6}{|l|}{ Banking market } \\
\hline Bank location dummy ${ }^{11}$ & 0.85 & 0.41 & 0.82 & 0.47 & -1.03 \\
\hline \multicolumn{6}{|c|}{$\begin{array}{l}{ }^{1} \text { Statistics computed at the time before the single relationship is substituted with multiple relationships. }{ }^{2} \text { The null } \\
\text { hypothesis of equal means is rejected at: } * * * 1 \%, * * 5 \%, * 10 \% .{ }^{3} \text { Coefficient of variation. }{ }^{4} \text { Dummy equals } 1 \text { if the firm } \\
\text { belongs to a conglomerate and } 0 \text { otherwise. }{ }^{5} \text { Value in billion escudos, } 1986 \text { prices. }{ }^{6} \text { Insider loans are defined as the sum } \\
\text { of loans extended by the firm's shareholders and associated firms. }{ }^{7} \text { Number of single relationships the firm had before it } \\
\text { replaced a single with multiple relationships. }{ }^{8} \text { Dummy equals } 1 \text { if the firm has past due loans with its bank when it } \\
\text { switches banks for the first time and } 0 \text { otherwise. }{ }^{9} \text { Dummy equals } 1 \text { if the firm had past due loans with its bank at any } \\
\text { time before it switched banks for the first time and } 0 \text { otherwise. }{ }^{10} \text { Ratio of bank loans to a single firm over bank's } \\
\text { equity. }{ }^{11} \text { Dummy equals } 1 \text { if the firm's single bank has a branch in the region where the firm is } \\
\text { headquartered. }\end{array}$} \\
\hline
\end{tabular}


Table 4

Firms that borrow for the first time from a single bank but later either switch banks or initiate multiple relationships

\begin{tabular}{|c|c|c|c|c|c|}
\hline \multirow{2}{*}{$\begin{array}{c}\text { Variables } \\
\text { Firm }\end{array}$} & \multicolumn{2}{|c|}{$\begin{array}{c}\text { Firms that switch } \\
\text { banks but retain a } \\
\text { single relationship } \\
{\text { (295 firms })^{1}}^{1}\end{array}$} & \multicolumn{2}{|c|}{$\begin{array}{l}\text { Firms that substitute a } \\
\text { single with multiple } \\
\text { relationships } \\
(707 \text { firms })^{2}\end{array}$} & \multirow[t]{2}{*}{$\begin{array}{l}\text { t-test for } \\
\text { difference } \\
\text { of means }\end{array}$} \\
\hline & Mean & $\mathrm{CV}^{4}$ & Mean & $\mathbf{C V}^{4}$ & \\
\hline Age (years) & 4.68 & 0.62 & 4.07 & 0.68 & $-3.15 * * *$ \\
\hline Conglomerate dummy ${ }^{5}$ & 0.02 & 6.43 & 0.03 & 5.59 & 0.64 \\
\hline Size $\left(\right.$ sales) ${ }^{6}$ & 0.09 & 4.25 & 0.52 & 9.36 & 1.51 \\
\hline Size (employees) & 27.34 & 3.37 & 54.13 & 4.54 & $1.82 *$ \\
\hline Sales growth $(\%)$ & 30.31 & 3.08 & 45.73 & 2.57 & $2.01 * *$ \\
\hline Liquidity/assets & 0.13 & 1.27 & 0.10 & 1.32 & $-2.66 * * *$ \\
\hline Intangibles/assets & 0.003 & 5.39 & 0.01 & 4.13 & $1.80 *$ \\
\hline Tangibles/total debt & 0.54 & 1.07 & 0.54 & 1.45 & -0.11 \\
\hline Investments/assets & 0.10 & 1.25 & 0.09 & 1.45 & -0.89 \\
\hline Investments/sales & 0.10 & 2.22 & 0.09 & 2.42 & -0.22 \\
\hline $\begin{array}{l}\text { Investment/ } \\
\text { (intangibles + tangibles) }\end{array}$ & 0.34 & 1.00 & 0.32 & 1.06 & -0.73 \\
\hline Cash flow/assets & 0.12 & 0.91 & 0.10 & 1.08 & $-2.10 * *$ \\
\hline Equity/assets & 0.28 & 0.73 & 0.25 & 0.74 & $-1.88^{*}$ \\
\hline Bank loans/assets & 0.06 & 1.83 & 0.11 & 1.34 & $4.58 * * *$ \\
\hline Trade credit/assets & 0.26 & 0.80 & 0.32 & 0.75 & 1.34 \\
\hline Insider loans/assets $^{7}$ & 0.19 & 1.20 & 0.18 & 1.22 & -0.89 \\
\hline \multicolumn{6}{|l|}{ Bank } \\
\hline Size (assets) ${ }^{6}$ & 586.85 & 0.87 & 577.72 & 0.77 & -0.28 \\
\hline Growth of assets (\%) & 18.57 & 2.24 & 16.31 & 2.38 & -0.82 \\
\hline Total lending/assets & 0.57 & 0.22 & 0.54 & 0.23 & $-4.13^{* * *}$ \\
\hline Liquidity/assets & 0.13 & 0.96 & 0.16 & 0.84 & $2.67 * * *$ \\
\hline Profits/assets & 0.01 & 1.31 & 0.01 & 0.93 & 1.14 \\
\hline \multicolumn{6}{|l|}{ Bank-firm relationship } \\
\hline Number of relationships $^{8}$ & 1.00 & - & 1.31 & 0.42 & - \\
\hline Single relationship duration (months) & 24.76 & 0.65 & 24.06 & 0.69 & -0.61 \\
\hline Bank long-term loans/bank debt & 0.05 & 4.19 & 0.10 & 2.76 & $2.88 * * *$ \\
\hline Past due loans dummy ${ }^{9}$ & 0.01 & 12.09 & 0.02 & 7.04 & 1.50 \\
\hline $\begin{array}{l}\text { Past due loans (accumulated) } \\
\text { dummy }^{10}\end{array}$ & 0.06 & 3.93 & 0.06 & 3.84 & 0.16 \\
\hline Risk exposure $^{11}$ & 0.0001 & 3.82 & 0.001 & 7.53 & $1.98 * *$ \\
\hline \multicolumn{6}{|l|}{ Banking market } \\
\hline Bank location dummy ${ }^{12}$ & 0.83 & 0.45 & 0.85 & 0.43 & 0.65 \\
\hline Banks in the market (number) & 12.57 & 0.63 & 11.71 & 0.62 & -1.62 \\
\hline \multicolumn{6}{|c|}{$\begin{array}{l}{ }^{1} \text { Statistics computed at the time before the firm switches banks for the first time. }{ }^{2} \text { Statistics computed at the time before } \\
\text { the firm initiates multiple relationships. }{ }^{3} \text { The null hypothesis of equal means is rejected at: } * * * 1 \%, * * 5 \%, * 10 \% \text {. } \\
{ }^{4} \text { Coefficient of variation. }{ }^{5} \text { Dummy equals } 1 \text { if the firm belongs to a conglomerate and } 0 \text { otherwise. }{ }^{6} \text { Value in billion } \\
\text { escudos, } 1986 \text { prices. }{ }^{7} \text { Insider loans are defined as the sum of loans extended by the firm's shareholders and associated } \\
\text { firms. }{ }^{8} \text { Number of single relationships that the firm had before it replaced a single with multiple relationships. }{ }^{9} \text { Dummy } \\
\text { equals } 1 \text { if the firm has past due loans with its bank when it switches banks for the first time and } 0 \text { otherwise. }{ }^{10} \text { Dummy } \\
\text { equals } 1 \text { if the firm had past due loans with its bank at any point in time before it switches banks for the first time and } 0 \\
\text { otherwise. }{ }^{11} \text { Ratio of bank loans to a single firm over bank's equity. }{ }^{12} \text { Dummy equals } 1 \text { if the firm's single bank has a } \\
\text { branch in the region where the firm is headquartered. }\end{array}$} \\
\hline
\end{tabular}


Table 5

Duration of single relationships: full parametric models (Weibull distribution) ${ }^{1}$

\begin{tabular}{|c|c|c|c|}
\hline Variables & $\begin{array}{c}\text { Model 1 } \\
(1,519 \text { firms })\end{array}$ & $\begin{array}{c}\text { Model } 2 \\
(1,577 \text { firms })\end{array}$ & $\begin{array}{c}\text { Model } 3 \\
(\mathbf{1 , 5 7 7} \text { firms })\end{array}$ \\
\hline Constant & $\begin{array}{l}3.790 \\
5.122 * * *\end{array}$ & $\begin{array}{l}3.500 \\
5.378 * * *\end{array}$ & $\begin{array}{c}4.241 \\
17.141 * * *\end{array}$ \\
\hline \multicolumn{4}{|l|}{ Firm } \\
\hline Conglomerate dummy $^{2}$ & $\begin{array}{l}-0.497 \\
-3.024 * * *\end{array}$ & $\begin{array}{l}-0.527 \\
-3.253 * * *\end{array}$ & $\begin{array}{l}-0.516 \\
-3.130 * * *\end{array}$ \\
\hline $\begin{array}{l}\text { Log of sales (thousand escudos, } \\
1986 \text { prices) }\end{array}$ & $\begin{array}{l}-0.110 \\
-5.479 * * *\end{array}$ & $\begin{array}{l}-0.108 \\
-5.414 * * *\end{array}$ & $\begin{array}{l}-0.120 \\
-6.545 * * *\end{array}$ \\
\hline Sales growth $(\%)$ & $\begin{array}{l}-0.001 \\
-6.110 * * *\end{array}$ & $\begin{array}{l}-0.001 \\
-6.386 * * *\end{array}$ & $\begin{array}{l}-0.001 \\
-6.532 * * *\end{array}$ \\
\hline Liquidity/assets & $\begin{array}{l}0.429 \\
2.048 * *\end{array}$ & $\begin{array}{l}0.431 \\
2.112 * *\end{array}$ & $\begin{array}{l}0.426 \\
2.107 * *\end{array}$ \\
\hline Intangibles /assets & $\begin{array}{l}-1.682 \\
-1.423\end{array}$ & $\begin{array}{l}-1.707 \\
-1.470\end{array}$ & $\begin{array}{l}-1.748 \\
-1.599\end{array}$ \\
\hline Tangibles/total debt & $\begin{array}{l}-0.038 \\
-0.651\end{array}$ & $\begin{array}{l}-0.048 \\
-0.934\end{array}$ & $\begin{array}{l}-0.046 \\
-0.891\end{array}$ \\
\hline $\begin{array}{l}\text { Investments/(intangibles } \\
+ \text { tangibles) }\end{array}$ & $\begin{array}{l}-0.223 \\
-2.879 * * *\end{array}$ & $\begin{array}{l}-0.220 \\
-2.889 * * *\end{array}$ & $\begin{array}{l}-0.228 \\
-3.025 * * *\end{array}$ \\
\hline Cash flow/assets & $\begin{array}{l}0.312 \\
1.273\end{array}$ & $\begin{array}{l}0.238 \\
0.980\end{array}$ & $\begin{array}{l}0.244 \\
1.016\end{array}$ \\
\hline Bank loans/assets & $\begin{array}{l}-0.223 \\
-4.634 * * *\end{array}$ & $\begin{array}{l}-1.020 \\
-4.780 * * *\end{array}$ & $\begin{array}{l}-1.087 \\
-5.464 * * *\end{array}$ \\
\hline Trade credit/assets & $\begin{array}{r}-0.112 \\
-0.614\end{array}$ & $\begin{array}{l}-0.152 \\
-0.882\end{array}$ & $\begin{array}{l}-0.153 \\
-0.901\end{array}$ \\
\hline Insider debt/assets & $\begin{array}{l}-0.110 \\
-0.701\end{array}$ & $\begin{array}{l}-0.099 \\
-0.654\end{array}$ & $\begin{array}{l}-0.116 \\
-0.775\end{array}$ \\
\hline \multicolumn{4}{|l|}{ Bank } \\
\hline $\begin{array}{l}\text { Log of assets (million escudos, } \\
1986 \text { prices) }\end{array}$ & $\begin{array}{l}0.045 \\
1.020\end{array}$ & $\begin{array}{l}0.042 \\
1.021\end{array}$ & - \\
\hline Age dummy & $\begin{array}{l}-0.108 \\
-1.136\end{array}$ & $\begin{array}{l}-0.125 \\
-1.341\end{array}$ & - \\
\hline Assets growth (\%) & $\begin{array}{l}0.001 \\
0.892\end{array}$ & $\begin{array}{l}0.001 \\
0.997\end{array}$ & - \\
\hline Liquidity/assets & $\begin{array}{r}-0.532 \\
-0.057\end{array}$ & $\begin{array}{l}0.157 \\
0.222\end{array}$ & - \\
\hline Profits/assets & $\begin{array}{l}7.285 \\
1.214 \\
\end{array}$ & $\begin{array}{l}8.172 \\
1.442 \\
\end{array}$ & - \\
\hline \multicolumn{4}{|l|}{ Bank-firm relationship } \\
\hline Number of switches $^{3}$ & $\begin{array}{l}0.058 \\
1.107 \\
\end{array}$ & $\begin{array}{l}0.065 \\
1.266 \\
\end{array}$ & $\begin{array}{l}0.063 \\
1.272 \\
\end{array}$ \\
\hline Bank long-term loans/bank debt & $\begin{array}{l}0.120 \\
1.159\end{array}$ & $\begin{array}{l}0.104 \\
1.019\end{array}$ & $\begin{array}{l}0.111 \\
1.100\end{array}$ \\
\hline Past due loans dummy ${ }^{4}$ & $\begin{array}{l}-0.383 \\
-1.810 *\end{array}$ & $\begin{array}{l}-0.398 \\
-1.973 *\end{array}$ & $\begin{array}{l}-0.386 \\
-1.881 *\end{array}$ \\
\hline Risk exposure $^{5}$ & $\begin{array}{l}-0.011 \\
-1.960 * *\end{array}$ & $\begin{array}{l}-0.009 \\
-1.260\end{array}$ & - \\
\hline \multicolumn{4}{|l|}{ Banking market } \\
\hline Bank location dummy $^{6}$ & $\begin{array}{l}0.166 \\
1.873 *\end{array}$ & - & - \\
\hline Banks in the market (number) & $\begin{array}{l}0.001 \\
0.245\end{array}$ & - & - \\
\hline $\begin{array}{l}P \\
H_{0}: p \leq 1\end{array}$ & $\begin{array}{c}1.535 \\
10.524 * * *\end{array}$ & $\begin{array}{c}1.536 \\
11.013 * * *\end{array}$ & $\begin{array}{c}1.520 \\
10.862 * * *\end{array}$ \\
\hline Median of the duration (months) & 56.014 & 52.786 & 53.147 \\
\hline $\mathrm{LR}^{7}$ (degrees of freedom) & $21.000 * * *(2)$ & $15.776 * *(6)$ & - \\
\hline \multicolumn{4}{|c|}{$\begin{array}{l}{ }^{1} \text { Models estimated with time dummies. The null hypothesis is rejected at: } * * * 1 \%, * * 5 \%, * 10 \% .{ }^{2} \text { Dummy equals } 1 \text { if } \\
\text { the firm belongs to a conglomerate. }{ }^{3} \text { Number of times firms switch banks before they initiate multiple relationships. } \\
{ }^{4} \text { Dummy equals } 1 \text { if the firm had past due bank loans before it changed from single to multiple relationships. }{ }^{5} \text { Ratio of } \\
\text { bank loans to a single firm over the bank's equity. }{ }^{6} \text { Dummy equals } 1 \text { if the firm's single bank has a branch in the } \\
\text { region where the firm is headquartered. }{ }^{7} \text { Model } 1 \text { versus model } 2 \text {, and model } 2 \text { versus model } 3 \text {, respectively. }\end{array}$} \\
\hline
\end{tabular}


Table 6

Duration of single relationships: semi-parametric model (Cox model) ${ }^{1}$

\begin{tabular}{|c|c|c|c|}
\hline Variables & $\begin{array}{c}\text { Model 1 } \\
(1,519 \text { firms }) \\
\end{array}$ & $\begin{array}{c}\text { Model } 2 \\
(1,577 \text { firms }) \\
\end{array}$ & $\begin{array}{c}\text { Model 3 } \\
(1,577 \text { firms }) \\
\end{array}$ \\
\hline \multicolumn{4}{|l|}{ Firm } \\
\hline Conglomerate dummy $^{2}$ & $\begin{array}{l}-0.705 \\
-2.826 * * *\end{array}$ & $\begin{array}{l}-0.755 \\
-3.057 * * * \\
\end{array}$ & $\begin{array}{l}-0.756 \\
-3.053 * * * \\
\end{array}$ \\
\hline $\begin{array}{l}\text { Log of sales (thousand } \\
\text { escudos, } 1986 \text { prices) }\end{array}$ & $\begin{array}{l}-0.182 \\
-5.623 * * *\end{array}$ & $\begin{array}{l}-0.177 \\
-5.375 * * *\end{array}$ & $\begin{array}{l}-0.181 \\
-5.944 * * *\end{array}$ \\
\hline Sales growth $(\%)$ & $\begin{array}{l}-0.002 \\
-5.632 * * *\end{array}$ & $\begin{array}{l}-0.002 \\
-5.763 * * *\end{array}$ & $\begin{array}{l}-0.002 \\
-5.872 * * *\end{array}$ \\
\hline Liquidity/assets & $\begin{array}{l}0.660 \\
2.125^{* *} \\
\end{array}$ & $\begin{array}{l}0.666 \\
2.214 * * \\
\end{array}$ & $\begin{array}{l}0.640 \\
2.129 * * \\
\end{array}$ \\
\hline Intangibles/assets & $\begin{array}{l}-2.292 \\
-1.495 \\
\end{array}$ & $\begin{array}{l}-2.328 \\
-1.575 \\
\end{array}$ & $\begin{array}{l}-2.369 \\
-1.673 \\
\end{array}$ \\
\hline Tangibles/total debt & $\begin{array}{l}-0.059 \\
-1.145 \\
\end{array}$ & $\begin{array}{l}-0.074 \\
-1.472 \\
\end{array}$ & $\begin{array}{l}-0.070 \\
-1.377 \\
\end{array}$ \\
\hline $\begin{array}{l}\text { Investments/(intangibles + } \\
\text { tangibles) }\end{array}$ & $\begin{array}{l}-0.339 \\
-2.702 * * *\end{array}$ & $\begin{array}{l}-0.337 \\
-2.697 * * *\end{array}$ & $\begin{array}{l}-0.339 \\
-2.700 * * *\end{array}$ \\
\hline Cash flow/assets & $\begin{array}{l}0.539 \\
1.629 *\end{array}$ & $\begin{array}{l}0.435 \\
1.310 \\
\end{array}$ & $\begin{array}{l}0.425 \\
1.303 \\
\end{array}$ \\
\hline Bank loans/assets & $\begin{array}{l}-1.629 \\
-4.785 * * *\end{array}$ & $\begin{array}{l}-1.587 \\
-4.921 * * *\end{array}$ & $\begin{array}{l}-1.595 \\
-5.034 * * *\end{array}$ \\
\hline Trade credit/assets & $\begin{array}{l}-0.145 \\
-0.577 \\
\end{array}$ & $\begin{array}{l}-0.186 \\
-0.783 \\
\end{array}$ & $\begin{array}{l}-0.212 \\
-0.893 \\
\end{array}$ \\
\hline Insider debt/assets & $\begin{array}{l}-0.174 \\
-0.768 \\
\end{array}$ & $\begin{array}{l}-0.147 \\
-0.677 \\
\end{array}$ & $\begin{array}{l}0.170 \\
0.792 \\
\end{array}$ \\
\hline \multicolumn{4}{|l|}{ Bank } \\
\hline $\begin{array}{l}\text { Log of assets (million } \\
\text { escudos, } 1986 \text { prices) }\end{array}$ & $\begin{array}{l}0.091 \\
1.380\end{array}$ & $\begin{array}{l}0.092 \\
1.529\end{array}$ & - \\
\hline Age dummy & $\begin{array}{l}-0.128 \\
-0.961\end{array}$ & $\begin{array}{l}-0.150 \\
-1.156\end{array}$ & - \\
\hline Assets growth (\%) & $\begin{array}{l}0.001 \\
0.603\end{array}$ & $\begin{array}{l}0.001 \\
0.665\end{array}$ & - \\
\hline Liquidity/assets & $\begin{array}{l}-0.137 \\
-0.110\end{array}$ & $\begin{array}{l}0.084 \\
0.089\end{array}$ & - \\
\hline Profits/assets & $\begin{array}{l}8.985 \\
0.966\end{array}$ & $\begin{array}{l}9.165 \\
1.055\end{array}$ & - \\
\hline \multicolumn{4}{|l|}{ Bank-firm relationship } \\
\hline Number of switches $^{3}$ & $\begin{array}{l}0.088 \\
1.166 \\
\end{array}$ & $\begin{array}{l}0.099 \\
1.332 \\
\end{array}$ & $\begin{array}{l}0.089 \\
1.219 \\
\end{array}$ \\
\hline $\begin{array}{l}\text { Bank long-term loans/bank } \\
\text { debt }\end{array}$ & $\begin{array}{l}0.186 \\
1.169 \\
\end{array}$ & $\begin{array}{l}0.153 \\
1.007 \\
\end{array}$ & $\begin{array}{l}0.155 \\
1.016 \\
\end{array}$ \\
\hline Past due loans dummy ${ }^{4}$ & $\begin{array}{l}-0.552 \\
-1.905^{*}\end{array}$ & $\begin{array}{l}-0.573 \\
-2.064 * *\end{array}$ & $\begin{array}{l}-0.543 \\
-1.968 *\end{array}$ \\
\hline \multicolumn{4}{|l|}{ Banking market } \\
\hline Bank location dummy $^{5}$ & $\begin{array}{l}0.227 \\
1.743 * \\
\end{array}$ & - & - \\
\hline $\begin{array}{l}\text { Banks in the market } \\
\text { (number) }\end{array}$ & $\begin{array}{l}0.002 \\
0.278\end{array}$ & - & - \\
\hline $\mathrm{LR}^{6}$ (degrees of freedom) & $4.302(2)$ & $8.910(5)$ & - \\
\hline $\begin{array}{l}{ }^{1} \text { Models estimated with time } \\
{ }^{2} \text { Dummy equals } 1 \text { if the firm b } \\
\text { they initiate multiple relations } \\
\text { changed from single to multi } \\
\text { branch in the region where the } \\
\text { model 3, respectively. }\end{array}$ & $\begin{array}{l}\text { The null hy } \\
\text { a conglomer } \\
\text { Oummy equal } \\
\text { onships. }{ }^{5} \mathrm{D} \\
\text { eeadquartered }\end{array}$ & $\begin{array}{l}\text { is rejected at: } \\
\text { mber of times } \\
\text { firm had past } \\
\text { juals } 1 \text { if the } \\
11 \text { versus mod }\end{array}$ & $\begin{array}{l}\%, * * 5 \%, * 10 \\
\text { witch banks bef } \\
\text { ank loans befor } \\
\text { single bank ha } \\
\text { nd model } 2 \text { ver }\end{array}$ \\
\hline
\end{tabular}


Table 7

Duration of single relationships: parametric models (Weibull distribution) with time-varying explanatory variables ${ }^{1}$

\begin{tabular}{|c|c|c|c|}
\hline Variables & $\begin{array}{c}\text { Model } 1 \\
(1,471 \text { firms })\end{array}$ & $\begin{array}{c}\text { Model } 2 \\
(1,577 \text { firms })\end{array}$ & $\begin{array}{c}\text { Model 3 } \\
(1,577 \text { firms })\end{array}$ \\
\hline Constant & $\begin{array}{l}4.811 \\
5.483 * * *\end{array}$ & $\begin{array}{l}4.790 \\
6.522 * * *\end{array}$ & $\begin{array}{c}5.963 \\
18.495 * * *\end{array}$ \\
\hline \multicolumn{4}{|l|}{ Firm } \\
\hline Conglomerate dummy $^{2}$ & $\begin{array}{l}-0.262 \\
-1.337\end{array}$ & $\begin{array}{l}-0.345 \\
-1.767 *\end{array}$ & $\begin{array}{l}-0.337 \\
-1.695 *\end{array}$ \\
\hline $\begin{array}{l}\text { Log of sales (thousand escudos, } \\
1986 \text { prices) }\end{array}$ & $\begin{array}{l}-0.213 \\
-8.065 * * *\end{array}$ & $\begin{array}{l}-0.199 \\
-8.128 * * *\end{array}$ & $\begin{array}{l}-0.210 \\
-9.158 * * *\end{array}$ \\
\hline Sales growth $(\%)$ & $\begin{array}{l}-0.001 \\
-4.343 * * *\end{array}$ & $\begin{array}{l}-0.001 \\
-4.830 * * *\end{array}$ & $\begin{array}{l}-0.001 \\
-4.894 * * *\end{array}$ \\
\hline Liquidity/assets & $\begin{array}{l}0.758 \\
3.015 * * *\end{array}$ & $\begin{array}{l}0.673 \\
2.739 * * *\end{array}$ & $\begin{array}{l}0.670 \\
2.717 * * *\end{array}$ \\
\hline Intangibles/assets & $\begin{array}{l}-0.910 \\
-0.749\end{array}$ & $\begin{array}{l}-0.869 \\
-0.717\end{array}$ & $\begin{array}{l}-0.837 \\
-0.690\end{array}$ \\
\hline Tangibles/total debt & $\begin{array}{l}0.045 \\
1.010\end{array}$ & $\begin{array}{l}0.035 \\
0.781\end{array}$ & $\begin{array}{l}0.037 \\
0.858\end{array}$ \\
\hline $\begin{array}{l}\text { Investments/(intangibles + } \\
\text { tangibles) }\end{array}$ & $\begin{array}{l}-0.147 \\
-1.947 *\end{array}$ & $\begin{array}{l}-0.156 \\
-2.044 * *\end{array}$ & $\begin{array}{l}-0.155 \\
-2.032 * *\end{array}$ \\
\hline Cash flow/assets & $\begin{array}{l}0.680 \\
2.482 * * *\end{array}$ & $\begin{array}{l}0.589 \\
2.055 * *\end{array}$ & $\begin{array}{l}0.572 \\
2.012 * *\end{array}$ \\
\hline Bank loans/assets & $\begin{array}{l}-1.517 \\
-5.978 * * *\end{array}$ & $\begin{array}{l}-1.608 \\
-6.509 * * *\end{array}$ & $\begin{array}{l}-1.699 \\
-6.911 * * *\end{array}$ \\
\hline Trade credit/assets & $\begin{array}{l}-0.113 \\
-0.582\end{array}$ & $\begin{array}{l}-0.144 \\
-0.779\end{array}$ & $\begin{array}{l}-0.145 \\
-0.779\end{array}$ \\
\hline Insider debt/assets & $\begin{array}{l}-0.109 \\
-0.581\end{array}$ & $\begin{array}{l}-0.074 \\
-0.417\end{array}$ & $\begin{array}{l}-0.087 \\
-0.494\end{array}$ \\
\hline \multicolumn{4}{|l|}{ Bank } \\
\hline $\begin{array}{l}\text { Log of assets (million escudos, } \\
1986 \text { prices) }\end{array}$ & $\begin{array}{l}0.055 \\
1.146\end{array}$ & $\begin{array}{l}0.050 \\
1.111\end{array}$ & - \\
\hline Age dummy & $\begin{array}{l}-0.012 \\
-0.111\end{array}$ & $\begin{array}{l}0.009 \\
0.077\end{array}$ & - \\
\hline Assets growth (\%) & $\begin{array}{l}0.001 \\
0.637\end{array}$ & $\begin{array}{l}0.001 \\
0.802\end{array}$ & - \\
\hline Liquidity/assets & $\begin{array}{l}1.392 \\
1.308 \\
\end{array}$ & $\begin{array}{l}1.185 \\
1.609 \\
\end{array}$ & - \\
\hline Profits/assets & $\begin{array}{l}0.961 \\
0.137\end{array}$ & $\begin{array}{l}0.858 \\
0.132\end{array}$ & - \\
\hline \multicolumn{4}{|l|}{ Bank-firm relationship } \\
\hline Number of switches ${ }^{3}$ & $\begin{array}{l}-0.175 \\
-2.733 * * *\end{array}$ & $\begin{array}{l}-0.146 \\
-2.349 * *\end{array}$ & $\begin{array}{l}-0.143 \\
-2.334 * *\end{array}$ \\
\hline Bank long-term loans/Bank debt & $\begin{array}{l}0.132 \\
1.128\end{array}$ & $\begin{array}{l}0.113 \\
0.993\end{array}$ & $\begin{array}{l}0.127 \\
1.111\end{array}$ \\
\hline Past due loans dummy ${ }^{4}$ & $\begin{array}{l}-0.676 \\
-3.569 * * *\end{array}$ & $\begin{array}{l}-0.787 \\
-4.152 * * *\end{array}$ & $\begin{array}{l}-0.847 \\
-4.346 * * *\end{array}$ \\
\hline Risk exposure $^{5}$ & $\begin{array}{l}-0.010 \\
-1.187\end{array}$ & $\begin{array}{l}-0.009 \\
-1.007\end{array}$ & - \\
\hline \multicolumn{4}{|l|}{ Banking market } \\
\hline Bank location dummy ${ }^{6}$ & $\begin{array}{l}-0.042 \\
-0.395\end{array}$ & - & - \\
\hline Banks in the market (number) & $\begin{array}{l}0.005 \\
0.853\end{array}$ & - & - \\
\hline $\begin{array}{l}P \\
H_{0}: p \leq 1\end{array}$ & $\begin{array}{l}1.370 \\
6.939 * * *\end{array}$ & $\begin{array}{l}1.344 \\
6.927 * * *\end{array}$ & $\begin{array}{l}1.336 \\
6.876 * * *\end{array}$ \\
\hline Median of the duration (months) & 57.050 & 54.663 & 54.843 \\
\hline $\mathrm{LR}^{7}$ (degrees of freedom) & $0.874(2)$ & $8.648(6)$ & - \\
\hline \multicolumn{4}{|c|}{$\begin{array}{l}{ }^{1} \text { Models estimated with time dummies. The null hypothesis is rejected at: } * * * 1 \%, * * 5 \%, * 10 \% .{ }^{2} \text { Dummy equals } 1 \text { if } \\
\text { the firm belongs to a conglomerate. }{ }^{3} \text { Number of times firms switch banks before they initiate multiple relationships } \\
{ }^{4} \text { Dummy equals } 1 \text { if the firm had past due bank loans before it changed from single to multiple relationships. }{ }^{5} \text { Ratio of } \\
\text { bank loans to a single firm over the bank's equity. }{ }^{6} \text { Dummy equals } 1 \text { if the firm's single bank has a branch in the } \\
\text { region where the firm is headquartered. }{ }^{7} \text { Model } 1 \text { versus model } 2 \text {, and model } 2 \text { versus model } 3 \text {, respectively. }\end{array}$} \\
\hline
\end{tabular}


Table 8

\section{Duration of single relationships for firms that do not switch banks before they start multiple relationships: parametric models (Weibull distribution) with time-varying explanatory variables ${ }^{1}$}

\begin{tabular}{|c|c|c|c|}
\hline Variables & $\begin{array}{c}\text { Model } 1 \\
(\mathbf{1 , 1 3 4} \text { firms })\end{array}$ & $\begin{array}{c}\text { Model } 2 \\
(1,218 \text { firms })\end{array}$ & $\begin{array}{c}\text { Model } 3 \\
(1,218 \text { firms })\end{array}$ \\
\hline Constant & $\begin{array}{l}4.657 \\
4.219 * * *\end{array}$ & $\begin{array}{l}4.914 \\
5.368 * * *\end{array}$ & $\begin{array}{c}6.324 \\
16.971 * * *\end{array}$ \\
\hline \multicolumn{4}{|l|}{ Firm } \\
\hline Conglomerate dummy ${ }^{2}$ & $\begin{array}{l}-0.272 \\
-1.136\end{array}$ & $\begin{array}{l}-0.258 \\
-1.083\end{array}$ & $\begin{array}{l}-0.267 \\
-1.108\end{array}$ \\
\hline $\begin{array}{l}\text { Log of sales (thousand escudos, } \\
1986 \text { prices) }\end{array}$ & $\begin{array}{l}-0.237 \\
-7.175 * * *\end{array}$ & $\begin{array}{l}-0.246 \\
-8.016 * * *\end{array}$ & $\begin{array}{l}-0.255 \\
-9.189 * * *\end{array}$ \\
\hline Sales growth $(\%)$ & $\begin{array}{l}-0.001 \\
-3.149 * * *\end{array}$ & $\begin{array}{l}-0.001 \\
-3.475 * * *\end{array}$ & $\begin{array}{l}-0.001 \\
-3.807 * * *\end{array}$ \\
\hline Liquidity/assets & $\begin{array}{l}1.224 \\
3.739 * * *\end{array}$ & $\begin{array}{l}1.007 \\
3.232 * * *\end{array}$ & $\begin{array}{l}1.001 \\
3.220 * * *\end{array}$ \\
\hline Intangibles/assets & $\begin{array}{l}-0.074 \\
-0.048\end{array}$ & $\begin{array}{l}0.001 \\
0.001\end{array}$ & $\begin{array}{l}-0.281 \\
-0.184\end{array}$ \\
\hline Tangibles/total debt & $\begin{array}{l}0.029 \\
0.538\end{array}$ & $\begin{array}{l}0.014 \\
0.265\end{array}$ & $\begin{array}{l}0.022 \\
0.415\end{array}$ \\
\hline $\begin{array}{l}\text { Investments/(intangibles + } \\
\text { tangibles) }\end{array}$ & $\begin{array}{l}-0.178 \\
-2.046 * *\end{array}$ & $\begin{array}{l}-0.184 \\
-2.184 * *\end{array}$ & $\begin{array}{l}-0.173 \\
-1.957 *\end{array}$ \\
\hline Cash flow/assets & $\begin{array}{l}0.649 \\
1.806 *\end{array}$ & $\begin{array}{l}0.546 \\
1.511 \\
\end{array}$ & $\begin{array}{l}0.551 \\
1.532 \\
\end{array}$ \\
\hline Bank loans/assets & $\begin{array}{l}-2.012 \\
-5.576 * * *\end{array}$ & $\begin{array}{l}-1.930 \\
-5.832 * * *\end{array}$ & $\begin{array}{l}-2.059 \\
-6.302 * * *\end{array}$ \\
\hline Trade credit/assets & $\begin{array}{l}-0.437 \\
-1.804 * ?\end{array}$ & $\begin{array}{l}-0.471 \\
-2.122 * *\end{array}$ & $\begin{array}{l}-0.494 \\
-2.229 * *\end{array}$ \\
\hline Insider debt/assets & $\begin{array}{l}-0.279 \\
-1.194\end{array}$ & $\begin{array}{l}-0.321 \\
-1.458\end{array}$ & $\begin{array}{l}-0.321 \\
-1.457\end{array}$ \\
\hline \multicolumn{4}{|l|}{ Bank } \\
\hline $\begin{array}{l}\text { Log of assets (million escudos, } \\
1986 \text { prices) }\end{array}$ & $\begin{array}{l}0.085 \\
1.235\end{array}$ & $\begin{array}{l}0.068 \\
1.150\end{array}$ & - \\
\hline Age dummy & $\begin{array}{l}-0.158 \\
-1.056\end{array}$ & $\begin{array}{l}-0.198 \\
-1.356\end{array}$ & - \\
\hline Assets growth (\%) & $\begin{array}{l}0.001 \\
0.734\end{array}$ & $\begin{array}{l}0.001 \\
0.828\end{array}$ & - \\
\hline Liquidity/assets & $\begin{array}{l}1.661 \\
1.390 \\
\end{array}$ & $\begin{array}{l}1.210 \\
1.528 \\
\end{array}$ & - \\
\hline Profits/assets & $\begin{array}{l}-1.386 \\
-0.151 \\
\end{array}$ & $\begin{array}{l}-1.421 \\
-0.568 \\
\end{array}$ & - \\
\hline \multicolumn{4}{|l|}{ Bank-firm relationship } \\
\hline Bank long-term loans/Bank debt & $\begin{array}{l}0.162 \\
1.117 \\
\end{array}$ & $\begin{array}{l}0.161 \\
1.175 \\
\end{array}$ & $\begin{array}{l}0.180 \\
1.317 \\
\end{array}$ \\
\hline Past due loans dummy ${ }^{3}$ & $\begin{array}{l}-0.961 \\
-3.355 * * *\end{array}$ & $\begin{array}{l}-1.080 \\
-3.979 * * *\end{array}$ & $\begin{array}{l}-1.121 \\
-3.791 * * *\end{array}$ \\
\hline Risk exposure $^{4}$ & $\begin{array}{l}-0.007 \\
-0.704\end{array}$ & $\begin{array}{l}-0.005 \\
-0.568\end{array}$ & - \\
\hline \multicolumn{4}{|l|}{ Banking market } \\
\hline Bank location dummy ${ }^{5}$ & $\begin{array}{l}-0.004 \\
-0.032\end{array}$ & - & - \\
\hline Banks in the market (number) & $\begin{array}{l}0.001 \\
0.094 \\
\end{array}$ & - & - \\
\hline $\begin{array}{l}P \\
H_{0}: p \leq 1\end{array}$ & $\begin{array}{l}1.286 \\
4.700 * * *\end{array}$ & $\begin{array}{l}1.281 \\
5.019 * * *\end{array}$ & $\begin{array}{l}1.274 \\
4.975 * * *\end{array}$ \\
\hline Median of the duration (months) & 62.634 & 58.354 & 58.911 \\
\hline $\mathrm{LR}^{6}$ (degrees of freedom) & $0.010(2)$ & $9.374(6)$ & - \\
\hline \multicolumn{4}{|c|}{$\begin{array}{l}{ }^{1} \text { Models estimated with time dummies. The null hypothesis is rejected at: *** } 1 \% \text {, ** 5\%, * } 10 \% \text {. } \\
2 \text { Dummy equals } 1 \text { if the firm belongs to a conglomerate. }{ }^{3} \text { Dummy equals } 1 \text { if the firm had past due bank } \\
\text { loans before it changed from single to multiple relationships. }{ }^{4} \text { Ratio of bank loans to a single firm over } \\
\text { the bank's equity. }{ }^{5} \text { Dummy equals } 1 \text { if the firm's single bank has a branch in the region where the firm is } \\
\text { headquartered. }{ }^{6} \text { Model } 1 \text { versus model } 2 \text {, and model } 2 \text { versus model } 3 \text {, respectively. }\end{array}$} \\
\hline
\end{tabular}


Table 9

Duration of single relationships: parametric models (Weibull distribution) with time-varying explanatory variables ${ }^{1}$

\begin{tabular}{|c|c|c|c|}
\hline Variables & $\begin{array}{c}\text { Model 1 } \\
(1,407 \text { firms })\end{array}$ & $\begin{array}{c}\text { Model 2 } \\
(1,510 \text { firms })\end{array}$ & $\begin{array}{c}\text { Model } 3 \\
(1,510 \text { firms })\end{array}$ \\
\hline Constant & $\begin{array}{l}4.842 \\
5.154 * * *\end{array}$ & $\begin{array}{l}4.897 \\
6.296^{* * *}\end{array}$ & $\begin{array}{c}6.266 \\
18.900^{* * * *}\end{array}$ \\
\hline \multicolumn{4}{|l|}{ Firm } \\
\hline Conglomerate dummy $^{2}$ & $\begin{array}{l}-0.278 \\
-1.251\end{array}$ & $\begin{array}{l}-0.386 \\
-1.756^{*}\end{array}$ & $\begin{array}{l}-0.381 \\
-1.711^{*}\end{array}$ \\
\hline $\begin{array}{l}\text { Log of sales (thousand escudos, } \\
1986 \text { prices) }\end{array}$ & $\begin{array}{l}-0.237 \\
-8.237 * * * \\
\end{array}$ & $\begin{array}{l}-0.218 \\
-8.275 * * *\end{array}$ & $\begin{array}{l}-0.230 \\
-9.363 * * *\end{array}$ \\
\hline Sales growth $(\%)$ & $\begin{array}{l}-0.001 \\
-3.240 * * *\end{array}$ & $\begin{array}{l}-0.001 \\
-4.020 * * *\end{array}$ & $\begin{array}{l}-0.001 \\
-4.064 * * *\end{array}$ \\
\hline Liquidity/assets & $\begin{array}{l}0.727 \\
2.633^{* * *} \\
\end{array}$ & $\begin{array}{l}-0.637 \\
-2.389 * * *\end{array}$ & $\begin{array}{l}0.634 \\
2.370^{* *}\end{array}$ \\
\hline Intangibles/assets & $\begin{array}{l}-1.257 \\
-0.847 \\
\end{array}$ & $\begin{array}{l}-1.131 \\
-0.767 \\
\end{array}$ & $\begin{array}{l}-1.160 \\
-0.778 \\
\end{array}$ \\
\hline Tangibles/total debt & $\begin{array}{l}0.034 \\
0.712\end{array}$ & $\begin{array}{l}0.027 \\
0.580\end{array}$ & $\begin{array}{l}0.032 \\
0.685\end{array}$ \\
\hline $\begin{array}{l}\text { Investments/(intangibles + } \\
\text { tangibles) }\end{array}$ & $\begin{array}{l}-0.134 \\
-1.513 \\
\end{array}$ & $\begin{array}{l}-0.142 \\
-1.582 \\
\end{array}$ & $\begin{array}{l}-0.140 \\
-1.545 \\
\end{array}$ \\
\hline Cash flow/assets & $\begin{array}{l}0.791 \\
3.015^{* * *}\end{array}$ & $\begin{array}{l}0.706 \\
2.353 * * \\
\end{array}$ & $\begin{array}{l}0.697 \\
2.343 * * \\
\end{array}$ \\
\hline Bank loans/assets & $\begin{array}{l}-1.730 \\
-6.196 * * *\end{array}$ & $\begin{array}{l}-1.799 \\
-6.648 * * *\end{array}$ & $\begin{array}{l}-1.910 \\
-7.106 * * *\end{array}$ \\
\hline Trade credit/assets & $\begin{array}{l}-0.173 \\
-0.825 \\
\end{array}$ & $\begin{array}{l}-0.196 \\
-0.986 \\
\end{array}$ & $\begin{array}{l}-0.203 \\
-1.015 \\
\end{array}$ \\
\hline Insider debt/assets & $\begin{array}{l}-0.167 \\
-0.823 \\
\end{array}$ & $\begin{array}{l}-0.120 \\
-0.638 \\
\end{array}$ & $\begin{array}{l}-0.132 \\
-0.702 \\
\end{array}$ \\
\hline \multicolumn{4}{|l|}{ Bank } \\
\hline $\begin{array}{l}\text { Log of assets (million escudos, } \\
1986 \text { prices) }\end{array}$ & $\begin{array}{l}0.073 \\
1.406 \\
\end{array}$ & $\begin{array}{l}0.060 \\
1.258 \\
\end{array}$ & - \\
\hline Age dummy & $\begin{array}{l}-0.043 \\
-0.366 \\
\end{array}$ & $\begin{array}{l}-0.015 \\
-0.028 \\
\end{array}$ & - \\
\hline Assets growth (\%) & $\begin{array}{l}0.0003 \\
0.334 \\
\end{array}$ & $\begin{array}{l}0.001 \\
0.578 \\
\end{array}$ & - \\
\hline Liquidity/assets & $\begin{array}{l}1.553 \\
1.384\end{array}$ & $\begin{array}{l}1.306 \\
1.732 *\end{array}$ & - \\
\hline Profits/assets & $\begin{array}{l}-1.049 \\
-0.138 \\
\end{array}$ & $\begin{array}{l}-0.461 \\
-0.067 \\
\end{array}$ & - \\
\hline \multicolumn{4}{|l|}{ Bank-firm relationship } \\
\hline Number of switches ${ }^{3}$ & $\begin{array}{l}-0.185 \\
-2.651 * * * \\
\end{array}$ & $\begin{array}{l}-0.149 \\
-2.206 * * \\
\end{array}$ & $\begin{array}{l}-0.146 \\
-2.203 * * \\
\end{array}$ \\
\hline Bank long-term loans/Bank debt & $\begin{array}{l}0.201 \\
1.551 \\
\end{array}$ & $\begin{array}{l}0.173 \\
1.392 \\
\end{array}$ & $\begin{array}{l}0.195 \\
1.556 \\
\end{array}$ \\
\hline Past due loans dummy ${ }^{4}$ & $\begin{array}{l}-0.675 \\
-3.039 * * *\end{array}$ & $\begin{array}{l}-0.815 \\
-3.730 * * *\end{array}$ & $\begin{array}{l}-0.885 \\
-3.888 * * *\end{array}$ \\
\hline Risk exposure $^{5}$ & $\begin{array}{l}-0.009 \\
-1.158 \\
\end{array}$ & $\begin{array}{l}-0.008 \\
-0.926 \\
\end{array}$ & - \\
\hline \multicolumn{4}{|l|}{ Banking market } \\
\hline Bank location dummy $^{6}$ & $\begin{array}{l}-0.077 \\
-0.670 \\
\end{array}$ & - & - \\
\hline Banks in the market (number) & $\begin{array}{l}0.007 \\
1.116\end{array}$ & - & - \\
\hline $\begin{array}{l}P \\
H_{0}: p \leq 1\end{array}$ & $\begin{array}{l}1.334 \\
5.985^{* * *}\end{array}$ & $\begin{array}{l}1.315 \\
6.042 * * *\end{array}$ & $\begin{array}{l}1.306 \\
5.988 * * *\end{array}$ \\
\hline Median of the duration (months) & 66.664 & 63.181 & 63.576 \\
\hline $\mathrm{LR}^{7}$ (degrees of freedom) & $1.502(2)$ & $8.016(6)$ & - \\
\hline \multicolumn{4}{|c|}{$\begin{array}{l}{ }^{1} \text { Restricted samples. Models estimated with time dummies. The null hypothesis is rejected at: *** } 1 \%, * * 5 \%, *{ }^{*} \text {, } \\
10 \% .{ }^{2} \text { Dummy equals } 1 \text { if the firm belongs to a conglomerate and } 0 \text { otherwise. }{ }^{3} \text { Number of times firms switch } \\
\text { banks before they initiate multiple relationships. }{ }^{4} \text { Dummy equals } 1 \text { if the firm had past due bank loans before it } \\
\text { changed from single to multiple relationships. }{ }^{5} \text { Ratio of bank loans to a single firm over the bank's equity. } \\
{ }^{6} \text { Dummy equals } 1 \text { if the firm's single bank has a branch in the region where the firm is headquartered. }{ }^{7} \text { Model } \\
1 \text { versus model 2, and model } 2 \text { versus model } 3 \text {, respectively. }\end{array}$} \\
\hline
\end{tabular}


Table 10

Importance of the relationship with the incumbent bank after the firm changes from single to multiple relationships ${ }^{1}$

\begin{tabular}{|l|c|c|c|c|c|c|c|}
\hline $\begin{array}{c}\text { Months after } \\
\text { firms start } \\
\text { multiple } \\
\text { relationships }\end{array}$ & $\begin{array}{c}\text { Number } \\
\text { of firms }\end{array}$ & \multicolumn{2}{|c|}{$\begin{array}{c}\text { Number of banks that the firm } \\
\text { borrows from }\end{array}$} & \multicolumn{3}{c|}{$\begin{array}{c}\text { of the firm's bank debt } \\
\text { borrowed from the incumbent } \\
\text { bank }\end{array}$} \\
\cline { 2 - 9 } & Mean & Median & CV $^{2}$ & Mean & Median & $\mathbf{C V}^{\mathbf{2}}$ \\
\hline $0-12$ & 707 & 2.0 & 2 & 0.35 & 62.6 & 66.8 & 0.51 \\
\hline $12-24$ & 560 & 2.2 & 2 & 0.51 & 60.0 & 62.5 & 0.57 \\
\hline $24-36$ & 407 & 2.4 & 2 & 0.61 & 56.4 & 56.3 & 0.62 \\
\hline$>36$ & 322 & 2.8 & 2 & 0.59 & 50.4 & 44.5 & 0.68 \\
\hline${ }^{1}$ Computations based on monthly observations. ${ }^{2}$ Coefficient of variation. \\
\hline
\end{tabular}


Table 11

Effects of firms' substitution of single with multiple relationships Models estimated with fixed effects ${ }^{1}$

\begin{tabular}{|c|c|c|c|c|c|c|}
\hline Variables & $\begin{array}{l}\text { Investment/ } \\
\text { (Intangibles } \\
\text { +Tangibles) }\end{array}$ & $\begin{array}{c}\text { Total debt/ } \\
\text { Assets }\end{array}$ & $\begin{array}{c}\text { Bank loans/ } \\
\text { Assets }\end{array}$ & $\begin{array}{c}\text { Trade } \\
\text { credit/ } \\
\text { Assets }\end{array}$ & $\begin{array}{c}\text { Insider } \\
\text { debt/ Assets }\end{array}$ & $\begin{array}{c}\text { Cash flow/ } \\
\text { Assets }\end{array}$ \\
\hline Multiple banks dummy ${ }^{2}$ & $\begin{array}{l}-0.392 \\
-0.144\end{array}$ & $\begin{array}{l}0.384 \\
0.554\end{array}$ & $\begin{array}{l}1.163 \\
1.992 * *\end{array}$ & $\begin{array}{l}2.307 \\
3.071 * * *\end{array}$ & $\begin{array}{l}-2.747 \\
-3.645 * * * \\
\end{array}$ & $\begin{array}{l}-0.533 \\
-0.992 \\
\end{array}$ \\
\hline Switch banks dummy $^{3}$ & $\begin{array}{l}7.331 \\
1.421\end{array}$ & $\begin{array}{l}-0.692 \\
-0.528\end{array}$ & $\begin{array}{l}2.576 \\
2.333^{* *}\end{array}$ & $\begin{array}{l}-3.079 \\
-2.166 * *\end{array}$ & $\begin{array}{l}-0.278 \\
-0.195\end{array}$ & $\begin{array}{l}-0.502 \\
-0.097\end{array}$ \\
\hline Log of age & $\begin{array}{r}-11.854 \\
-1.515\end{array}$ & $\begin{array}{l}-6.011 \\
-3.008 * * *\end{array}$ & $\begin{array}{l}3.145 \\
1.868 *\end{array}$ & $\begin{array}{l}-4.803 \\
-2.219 * *\end{array}$ & $\begin{array}{l}-1.665 \\
-0.767\end{array}$ & $\begin{array}{l}2.993 \\
1.929 *\end{array}$ \\
\hline Log of sales ${ }^{4}$ & $\begin{array}{l}-0.451 \\
-0.171 \\
\end{array}$ & $\begin{array}{l}0.640 \\
0.958 \\
\end{array}$ & $\begin{array}{l}2.650 \\
4.711^{* * * *}\end{array}$ & $\begin{array}{l}1.484 \\
2.079 * * \\
\end{array}$ & $\begin{array}{l}-2.623 \\
-3.665 * * * \\
\end{array}$ & $\begin{array}{l}-0.768 \\
-1.549 \\
\end{array}$ \\
\hline Liquidity/assets & $\begin{array}{l}0.521 \\
6.134 * * *\end{array}$ & $\begin{array}{l}-0.058 \\
-2.685^{* * *}\end{array}$ & $\begin{array}{l}-0.005 \\
-0.299\end{array}$ & $\begin{array}{l}-0.064 \\
-2.729 * * *\end{array}$ & $\begin{array}{l}-0.063 \\
-2.680 * * *\end{array}$ & - \\
\hline Tangibles/total debt & $\begin{array}{l}-0.001 \\
-0.682\end{array}$ & $\begin{array}{l}-0.0002 \\
-0.523\end{array}$ & $\begin{array}{l}-0.0003 \\
-0.752\end{array}$ & - & - & - \\
\hline $\begin{array}{l}\text { Investment/(intangibles } \\
+ \text { tangibles) }\end{array}$ & - & $\begin{array}{l}0.002 \\
0.371\end{array}$ & $\begin{array}{l}-0.004 \\
-0.897\end{array}$ & $\begin{array}{l}0.009 \\
1.537\end{array}$ & $\begin{array}{l}-0.001 \\
-0.088\end{array}$ & $\begin{array}{l}0.001 \\
0.284\end{array}$ \\
\hline Cash flow/assets & $\begin{array}{l}0.036 \\
0.309 \\
\end{array}$ & $\begin{array}{l}-0.214 \\
-7.790 * * *\end{array}$ & $\begin{array}{l}-0.077 \\
-3.343 * * *\end{array}$ & $\begin{array}{l}-0.040 \\
-1.329 \\
\end{array}$ & $\begin{array}{l}-0.105 \\
-3.514 * * * \\
\end{array}$ & - \\
\hline Total debt/assets & $\begin{array}{l}-0.144 \\
-1.704 *\end{array}$ & - & - & - & - & $\begin{array}{l}0.077 \\
5.035 * * *\end{array}$ \\
\hline Adjusted R-squared & 0.741 & 0.782 & 0.611 & 0.696 & 0.735 & 0.474 \\
\hline $\mathrm{F}\left(\mathrm{H}_{0}: \theta_{\mathrm{i}}=\theta, \forall \mathrm{i}\right)$ & 8.902 & 9.500 & 4.754 & 6.949 & 7.709 & 3.377 \\
\hline $\begin{array}{l}\text { Hausman test (degrees } \\
\text { of freedom) }\end{array}$ & $34.942(16)$ & $178.93(16)$ & $57.743(16)$ & $34.660(15)$ & $44.428(15)$ & $83.231(14)$ \\
\hline
\end{tabular}




\section{References}

Agelini, P, R Di Salvo and G Ferri (1998): "Availability and Cost of credit for Small Businesses: Customer Relationships and Credit Co-operatives". Journal of Banking and Finance, Vol. 22, pp. 925-954.

Berger, A N and G F Udell (1995): "Relationship Lending and Lines of Credit in Small Firm Finance”. Journal of Business, Vol. 68, pp. 351-381.

Bhattacharya, S and G Chiesa (1995): "Proprietary Information, Financial Intermediation, and Research Incentives". Journal of Financial Intermediation, Vol. 4, pp. 328-357.

Bhattacharya, S and Thakor, A V (1993): "Contemporary Banking Theory". Journal of Financial Intermediation, Vol. 3, pp. 2-50.

Blackwell, D W and D B Winters (1997) "Banking Relationships and the Effect of Monitoring on Loan Pricing". Journal of Financial Research, Vol. 20, pp. 275-289.

Blackwell, N R and A M Santomero (1982): "Bank Credit Rationing and the Customer Relation". Journal of Monetary Economics, Vol. 9, pp. 121-129.

Bolton, P and D S Scharfstein (1996): "Optimal Debt Structure and the Number of Creditors". Journal of Political Economy, Vol. 104, No. 1, pp. 1-25.

Boot, A W A, and Thakor, A V (forthcoming): “Can Relationship Banking survive Competition?". Journal Finance.

Boot, A W A and Thakor, A V (1994): "Moral Hazard and Secured Lending in an Infinitely Repeated Credit Market Game". International Economic Review, Vol. 35, No. 4, pp. 899-920.

Broecker, T (1990): “Credit-Worthiness Tests and Interbank Competition”. Econometrica, Vol. 58, pp. 429-452.

Bulow, J and J Shoven (1978): “The Bankruptcy Decision”. Bell Journal of Economics, Vol. 9, pp. 437-456.

Cole, R (1998): "The Importance of Relationships to the Availability of Credit". Journal of Banking and Finance, Vol. 22, pp. 959-977.

D'Auria, C, A Foglia and P M Reedtz (1999): "Bank Interest Rates and Credit Relationships in Italy". Journal of Banking and Finance, Vol. 23, pp. 1067-1093.

Degryse, H and P van Cayseele (1998) "Relationship Lending within a Bank-Based System: Evidence from European Small Business Data". Mimeo Tilburg University.

Detragiache, E, P G Garella and L Guiso (1997): "Multiple versus Single Banking Relationships". CEPR, Financial Economics, Discussion Papers Series, No. 1649.

Diamond, D W (1984): "Financial Intermediation and Delegated Monitoring". Review of Economic Studies, Vol. 51, No. 3, pp. 393-414.

Elliehausen, G E and J D Wolken (1993): "The Demand for Trade Credit: An Investigation of Motives for Trade Credit use by Small Businesses". Board of Governors of the Federal Reserve System, Study No. 165.

Elsas, R and J P Krahnen (1998): "Is Relationship Lending Special? Evidence from Credit-File Data in Germany”. Journal of Banking and Finance, Vol. 22, pp. 1283-1316.

Farinha, L A and J A C Santos (2000): "Cross Section and Over Time Changes in the Mix of a Firm's Funding Sources”. Mimeo, Bank for International Settlements.

Farrell, J and N Gallini (1988): "Second-Sourcing as a Commitment Device: Monopoly Incentives to Attract competition", Quarterly Journal of Economics, Vol. 103, pp. 673-694. 
Foglia, A, S Laviola and P Marullo Reedtz (1998): "Multiple Banking Relationships and the Fragility of Corporate Borrowers". Journal of Banking and Finance, Vol. 22, pp. 1441-1456.

Freixas, X and J C Rochet (1997): Microeconomics of Banking, Cambridge, Mass.: MIT Press.

Greenbaum, S I, G Kanatas and I Venezia (1989) "Equilibrium Loan Pricing Under the Bank-Client Relationship". Journal of Banking and Finance, Vol. 13, No. 2, pp. 221-235.

Hannan, T (1991): "Bank Commercial Loan Markets and the Role of Market Structure: Evidence from Surveys of Commercial Lending”. Journal of Banking and Finance, Vol. 15, pp. 133-149.

Harhoff, D and T Körting (1998a): "Lending Relationships in Germany: Empirical Evidence from Survey Data". Journal of Banking and Finance, Vol. 22, pp. 1317-1354.

Harhoff, D and T Körting (1998b): "How Many Creditors does it take to Tango?". Mimeo, Wissenschaftszentrum, Berlin.

Haubrich, J G (1989): "Financial Intermediation, Delegated Monitoring, and Long-term Relationships". Journal of Banking and Finance, Vol. 13, No. 1, pp. 19-20.

Hausman, J (1978): "Specification Tests in Econometrics". Econometrica, Vol. 46, pp. 1251-1271.

Houston, J F and C James (1996a): "Bank Information Monopolies and the Mix of Private and Public Debt Claims". Journal of Finance, Vol. 51, No. 5, pp. 1863-1889.

Houston, J F and C James (1996b): "Banking Relationships, Financial Constraints and Investment: Are Bank Dependent Borrowers more Financially Constrained?". Working Paper, Graduate School of Business Administration, University of Florida.

Lancaster, T (1990): The Econometric Analysis of Transition Data, Cambridge University Press.

Ongena, S and D C Smith (1999a): "Bank Relationships: A Review". Forthcoming in The Performance of Financial Institutions, P Harker and S A Zenios eds. Cambridge University Press.

Ongena, S and D C Smith (1999b): "What Determines the Number of Bank Relationships? Cross Country Evidence". Mimeo, Norwegian School of Management.

Ongena, S and D C Smith (1998): "Empirical Evidence on the Duration of Bank Relationships". Mimeo, Norwegian School of Management.

Petersen, M A and R G Rajan (1997): "Trade Credit Theories and evidence". Review of Financial Studies, Vol. 10, No. 3, pp. 661-691.

Petersen, M A and R G Rajan (1995): "The Effect of Credit Market Competition on Lending Relationships". Quarterly Journal of Economics, Vol. 110, pp. 406-443.

Petersen, M A and R G Rajan (1994): "The Benefits of Lending Relationships: Evidence from Small Business Data.”. Journal of Finance, Vol. 49, No. 1, pp. 3-37.

Rajan, R G (1992): “Insiders and Outsiders: The Choice between Informed and Arm's-Length Debt". Journal of Finance, Vol. 47, No. 4, pp. 1367-1400.

Santos, J A C (1998); "Banking and Commerce: How does the United States Compare to other Countries?". Federal Reserve Bank of Cleveland Economic Review, Vol. 34, No. 4, pp. 14-26.

Sharpe, S A (1990): "Asymmetric Information, Bank Lending and Implicit Contracts: A Stylised Model of Customer Relationships". Journal of Finance, Vol. 45, No. 4, pp. 1069-1087.

Shepard, A (1987): "Licensing to Enhance Demand for New Technologies". Rand Journal of Economics, Vol. 18, pp. 360-368.

von Rheinbaben, J and M Ruckes (1998): “A Firm's Optimal Number of Bank Relationships and the Extent of Information Disclosure". Mimeo, Universität Mannheim.

von Thadden, E L (1998): "Asymmetric Information, Bank Lending and Implicit Contracts: The Winner's Curse". Mimeo, University of Lausanne. 
von Thadden, E L (1995): "Long-Term Contracts, Short-Term Investment and Monitoring". Review of Economic Studies, Vol. 62, No. 4, pp. 557-575.

von Thadden, E L (1992): "The Commitment of Finance, Duplicated Monitoring, and the Investment Horizon”. WWZ Discussion Papers No. 9207.

Yosha, O (1995): "Information Disclosure Costs and the Choice of Financing Source". Journal of Financial Intermediation, Vol. 4, pp. 3-20. 



\section{Recent BIS Working Papers}

No.

67

May 1999

68

May 1999

69

June 1999

70

June 1999

71

June 1999

72

August 1999

73

August 1999

74

August 1999

75

August 1999

76

October 1999

77

October 1999

78

October 1999

79

November 1999

80

November 1999

81

November 1999

82

November 1999
The cyclical sensitivity of seasonality in US employment

The evolution of determinants of emerging market credit spreads in the 1990s

Credit channels and consumption in Europe: empirical evidence

Interbank exposures: quantifying the risk of contagion

The term structure of announcement effects

Reserve currency allocation: an alternative methodology

The Taylor rule and interest rates in the EMU area: a note

The dollar-mark axis

A note on the Gordon growth model with nonstationary dividend growth

The price of risk at year-end: evidence from interbank lending

Perceived central bank intervention and market expectations: an empirical study of the yen/dollar exchange rate, 1993-96

Banking and commerce: a liquidity approach

Pass-through of exchange rates and import prices to domestic inflation in some industrialised economies

A note on alternative measures of real bond rates

Interbank interest rates and the risk premium

Sacrifice ratios and the conduct of monetary policy in conditions of low inflation
Spencer Krane and William Wascher

Steven B Kamin and Karsten von Kleist

Gabe de Bondt

Craig H Furfine

Michael J Fleming and Eli M Remolona

Srichander Ramaswamy

Stefan Gerlach and Gert Schnabel

Gabriele Galati

Henri Pagès

Craig H Furfine

Gabriele Galati and William Melick

Joseph G Haubrich and João A C Santos

Jonathan McCarthy

Palle S Andersen

Henri Pagès

Palle S Andersen and William L Wascher 